\title{
SMALL GUMAROVO KURGANS OF SCYTHIAN-SARMATIAN TIME AT SOUTH URAL: CHRONOLOGY, FEATURES OF THE FUNERAL RITES AND ISSUES OF CULTURAL ATTRIBUTION
}

\author{
Nikita S. Savelev \\ Ufa Federal Research Center of the Russian Academy of Sciences, Ufa, Russian Federation
}

\begin{abstract}
The article presents an analysis of the burial rite and chronology of the Gumarovo cemetery, located on the border of the steppe and mountain-steppe zones of the Southern Urals, at the southern tip of the almost completely forested low plateau Zilair (Russia, Orenburg oblast, right bank of the Sakmara River). The cemetery consists of 5 stone kurgans, explored in 1979-1980 by an expedition led by R.B. Ismagilov. A burial of Early Scythian time was revealed in one of the kurgans (the so-called "Bolshoy Gumarovskiy", "Big Gumarovo"), and immediately became widely known among researchers. The cemetery itself belongs to a later time, also known as "Sauromatian" time. Based on the chronological indicators and simultaneous occurrence of accompanying inventory categories, it is determined that the cemetery dates back to the end of the $5^{\text {th }}$ - beginning of the $4^{\text {th }}$ centuries $\mathrm{BC}$ and existed for a very short time. The burial rite features of the Gumarovo kurgans (stone mounds, wide oval graves, sloping walls, circular chamber graves, heads of the deceased oriented to the west and the east) indicate that it belongs to a special "Mugodzharian" group of nomads from the Southern Urals steppes eastern part. The origin of this group of nomads is associated with the migration of the Northern and Central Kazakhstan nomads to the steppes of the Orsk-Ilek interfluve, i.e. to the west of the Mugodzhar ridge; with their long-lasting interaction with the local population of the Sauromatian (proved by Blumenfeld and East Aral complexes) and Early Sarmatian time; as well as assimilating part of the Early Saka appearance population, which occupied the steppes of the Southern Trans-Urals in the $7^{\text {th }}-6^{\text {th }}$ centuries BC. It is shown that it is the "Mugodzharian" features that make the kurgans in the eastern part of the Southern Urals steppes significantly specific.
\end{abstract}

Key words: Southern Urals, Mugodzhar ridge, Scythian-Sarmatian time, funeral rite, ethno-cultural diversity.

Citation. Savelev N.S., 2021. Malye Gumarovskie kurgany skifo-sarmatskogo vremeni na Yuzhnom Urale: hronologiya, osobennosti pogrebal'nogo obryada i voprosy kul'turnoy atributsii [Small Gumarovo Kurgans of Scythian-Sarmatian Time at South Ural: Chronology, Features of the Funeral Rites and Issues of Cultural Attribution]. Nizhnevolzhskiy Arkheologicheskiy Vestnik [The Lower Volga Archaeological Bulletin], vol. 20, no. 1, pp. 179-203. DOI: https://doi.org/10.15688/nav.jvolsu.2021.1.9

УДК 903'1(470.5):903.5

ББК 63.442.7(235.55)-427

Дата поступления статьи: 08.03.2021

Дата принятия статьи: 27.05.2021

\section{МАЛЫЕ ГУМАРОВСКИЕ КУРГАНЫ СКИФО-САРМАТСКОГО ВРЕМЕНИ НА ЮЖНОМ УРАЛЕ: ХРОНОЛОГИЯ, ОСОБЕННОСТИ ПОГРЕБАЛЬНОГО ОБРЯДА И ВОПРОСЫ КУЛЬТУРНОЙ АТРИБУЦИИ}

\author{
Никита Сергеевич Савельев \\ Уфимский федеральный исследовательский центр РАН, г. Уфа, Российская Федерация
}

Аннотация. Представлен анализ погребального обряда и хронологии Гумаровского курганного могильника, расположенного на границе степной и горно-степной зон Южного Урала, на южной оконечности низкогорного и практически полностью покрытого лесом Зилаирского плато (Россия, Оренбургская область, правый берег р. Сакмара). Могильник состоит из 5 каменных курганов, исследованных в 1979-1980 гг. 
экспедицией под руководством Р.Б. Исмагилова. В одном из курганов (так называемом «Большом Гумаровском») выявлено погребение раннескифского времени, сразу же получившее широкую известность у исследователей. Сам могильник относится к более позднему, «савроматскому», времени. На основе хронологических индикаторов и совстречаемости категорий сопровождающего инвентаря установлено, что могильник датируется концом V - началом IV вв. до н.э. и существовал очень недолго. Погребальный обряд Гумаровских курганов (каменные насыпи, широкие овальные могильные ямы, наклонные стенки и кольцевые ниши-полуподбои, ориентировка умерших головами на запад и восток) свидетельствует о его принадлежности к особой «мугоджарской» группе кочевников восточной части степей Южного Урала. Происхождение данной группы кочевников связывается с миграцией номадов Северного и Центрального Казахстана в степи Орско-Илекского междуречья, то есть к западу от Мугоджарского хребта, их длительным взаимодействием с местным населением савроматского (блюменфельдский и восточноприаральский комплексы) и раннесарматского времени, а также ассимиляцией части населения раннесакского облика, занимавшего степи Южного Зауралья в VII-VI вв. до н.э. Показано, что именно «мугоджарские» признаки придают значительную специфику памятникам восточной части степей Южного Урала.

Ключевые слова: Южный Урал, Мугоджары, скифо-сарматское время, погребальный обряд, этнокультурное разнообразие.

Цитирование. Савельев Н. С., 2021. Малые Гумаровские курганы скифо-сарматского времени на Южном Урале: хронология, особенности погребального обряда и вопросы культурной атрибуции // Нижневолжский археологический вестник. Т. 20, № 1. С. 179-203. DOI: https://doi.org/10.15688/nav.jvolsu.2021.1.9

Исследование на рубеже 1970-80-х гг. в одном из курганов могильника около д. Гумарово в Кувандыкском районе Оренбургской области погребения раннескифского (раннесакского) облика [Исмагилов, 1988] сразу же привлекло внимание специалистов и навсегда вписало его в список основных источников по раннему этапу скифской эпохи Евразийского кочевого пояса (см. напр.: [Ольховский, 2000; Чугунов, 2000; Исмагил, 2013]). Нужно отметить и то, что исследованный курган, получивший с легкой руки Р.Б. Исмагилова название Большого Гумаровского, входил в состав могильника с погребениями кочевников немного более поздней, «савроматской» эпохи [Зуев, Исмагилов, 1999; Исмагил, Сунгатов, 2013]. Продолжая предложенный автором исследований формат, все эти курганы могут быть названы «Малыми» ${ }^{1}$.

Гумаровский могильник расположен на границе степной и горно-степной зон Южного Урала, на южной оконечности низкогорного Зилаирского плато, к востоку от д. Гумарово, на распаханном пологом мысу правого берега р. Сакмара (рис. 1,1). Район расположения могильника только очень условно может быть назван «Южным Приуральем» (в случае, если под Приуральем понимать территории, примыкающие к р. Урал, что не является верным ни с физико-географической, ни с историко-географической точек зрения [Чибилев, Богданов, 2011; Чибилев, Чибилев, 2012; Савельев, 2011;
2017]), реально же это пограничная территория между Южным Приуральем и Южным Зауральем. Вероятно, даже более важным является то, что могильник находится непосредственно в пределах так называемых «Мугоджарских ворот» - узкого, не более 5070 км шириной, единственного степного прохода в Уральской горной стране (по крайней мере, единственного от долины р. Чусовая на Среднем Урале до южной оконечности Мугоджар в полупустынях к северу от Аральского моря), соединяющего азиатскую и европейскую части степного пояса.

Могильник представлял из себя вытянутую в широтном направлении компактную цепочку из 4 курганов, расстояние между соседними курганами составляет 5-10 м (рис. 2,A). Не более чем в 5 м к северу от центра цепочки находился курган № 1 (так называемый «Большой»). Как было установлено во время раскопок, его внушительные размеры (высота до разрушения в 1950-е гг. - более 2 м, диаметр - более 23 м) являлись следствием значительной досыпки первоначальной насыпи после совершения явно нерядового захоронения в савроматское время (рис. 2,1). Таким образом, к савроматской эпохе относятся 8 погребений (кург. 1 погр. 1, кург. 2 погр. 3 , кург. 3 погр. 1, кург. 4 - погр. 1, кург. 5 погр. 2), из них 3 (кург. 2 погр. 2, кург. 2 погр. 3 , кург. 5 погр. 2) являются впускными, то есть немного более поздними по времени. 
В отличие от раннескифского погребения, комплексы савроматского времени Гумаровских курганов (даже после их публикации [Зуев, Исмагилов, 1999]) не вызвали какоголибо особого внимания у исследователей. Так, например, Б.Ф. Железчиков при масштабной статистической обработке материалов савроматской эпохи Азиатской Сарматии использовал только материалы из кург. 4 Гумаровского могильника [Железчиков, 1994, с. 70, № 254], находящегося в центре курганной цепочки и мало чем отличающегося от соседних курганов [Зуев, Исмагилов, 1999, с. 108 109, табл. 8]. С.Ю. Гуцалов, занимаясь кочевническими древностями Орско-Уральского междуречья [Гуцалов, 2004], не использовал эти, новые к тому времени, материалы, вероятно, исключительно по территориальному признаку - Гумаровские курганы удалены от p. Урал на 30 км к северу. Впрочем, и сами авторы публикации, рассматривавшие только отдельные категории инвентаря, в плане культурной атрибуции всего лишь попутно заметили, что могильник относится к савроматской культуре, ничем по инвентарю не выделяясь из числа широко известных памятников этого времени (Пятимары I, Черниговский, Сара, Бесоба) [Зуев, Исмагилов, 1999, с. 110].

Вероятно, данное положение связано с тем, что с начала 1990-х гг. для большей части специалистов по эпохе ранних кочевников настало время теоретического осмысления, конструирования новых культур, отказа от них, замены существующих схем на концепцию культурно-хронологических горизонтов, отстаивания и опровержения существования хронологических лакун, попыток обосновать наличие «квазивековых» циклов солнечной активности, приводящих к кардинальным этнокультурным перестройкам в кочевом мире, сквозных хронологизаций и проч. (см. напр.: [Яблонский, 2007 и др.; Пшеничнюк, 1995; Васильев, 2004; Таиров, 2007; Таиров, 2015; Таиров, 2016; Берлизов, 2011; Исмагил, Сунгатов, 2011; Исмагил, Сунгатов, 2013; и т. д.]). Во всех этих исканиях сами археологические материалы занимали исключительно подчиненное положение. Работы структурного характера в это время стали больше исключением, чем правилом [Яблонский, 2010; Мышкин, 2012; Мышкин, 2013].
Обращение к опубликованным и неопубликованным [Исмагилов, 1980; Исмагилов, 1981] материалам Гумаровских курганов, в том числе и ознакомление с самой коллекцией ${ }^{2}$ позволяет вернуться к анализу этого могильника и определить его место и место других подобных памятников в общей картине «савроматской» эпохи в центральной части Евразийской степи.

Близость погребального обряда (табл. 1, 2) и сопровождающего инвентаря (табл. 3) позволяют уверенно говорить о существовании могильника в достаточно короткий отрезок времени и захоронении в нем членов родственного коллектива. Все курганы сложены из камня крупного и среднего размера, диаметр кург. 2-5 составляет 10-12 м, высота 0,260,51 м, размеры кург. 1 намного большие-диаметр 23 м, высота - более 2 метров ${ }^{3}$. Курганы 1, 3 и 4 были возведены над единственными центральными погребениями, в кург. 2 и 5 присутствовали также и впускные погребения - в первом их два, во втором - одно. Ни в одном кургане под насыпями каких-либо каменных конструкций не прослежено, только для кург. 1 отмечается, что самые крупные камни (весом до 100 кг) располагались по периферии насыпи, образуя что-то типа крепиды [Исмагилов, 1981, л. 2].

В двух случаях (кург. 1 и 2) вокруг центральных погребений зафиксировано кольцо могильного выкида. В кург. 1 («Большом») внешний диаметр кольцевого валика достигал 12 м, ширина составляла 4-4,5 м, высота 0,7 метра. В обоих случаях могильные ямы были перекрыты достаточно мощным деревянным накатом, при этом в кург. 1 он фиксировался внутри кольцевого валика, на древнем горизонте, в кург. 2 перекрытие было уложено на вершину кольцевого валика, внешний диаметр которого составлял 5 метров. В кург. 2 перекрытие было полностью сожжено, в кург. 1 на перекрытии, также провалившемся, костер был разведен только в западной его части. Следы провалившегося перекрытия в кург. 1, «...сожженного, вероятно, не полностью, были прослежены вдоль всего края могилы в виде желтоватого тлена мощностью около 0,25 м» [Исмагилов, 1981, л. 3].

Во всех курганах, за исключением кург. 5, под камнями насыпей, на уровне древ- 
него горизонта присутствуют различные находки. В кург. 1 это перевернутый круглый жертвенник на трех ножках и бронзовое зеркало (рис. 2,3,5), лежавшие у западного края могильной ямы. Также каменный жертвенник овальный с рифленым бортиком и четырьмя короткими ножками - находился в перевернутом виде у восточного края могильной ямы кург. 3 (рис. 4,9), а в центре кургана под камнями найдено несколько фрагментов керамики с примесью талька в тесте. В восточной поле кург. 2 найдены практически полный развал неорнаментированного яйцевидного сосуда с примесью талька в тесте (рис. 3,17 ), а также несколько фрагментов от другого сосуда, с примесью шамота. В восточной поле кург. 4 найдены разрозненные кости животных.

Всего одна могильная яма из восьми исследованных имеет прямоугольную форму (кург. 2, погр. 2), все остальные - овальные. Размеры их очень крупные, длина составляет 2,7-3,8 м, ширина для впускных и основных погребений различается: первые значительно более узкие (соотношение длина / ширина составляет $1: 1,8$ и 1:2,7-3), вторые широкие - их соотношение длина / ширина не превышает 1:1,15-1,5 (табл. 1). Размеры могильной ямы в кург. $1-6 \times 5,2$ м (то есть $1: 1,16)$, глубина - 2,2 м, форма овальная, близкая ромбической с закругленными углами, то есть от остальных основных погребений могильника она отличается только своими более крупными размерами. Распределение могильных ям по глубинам показывает примерно такую же закономерность: наиболее глубокими являются основные погребения (кург. 1 - 2,2 м; кург. 2, погр. 1 - 1,43 м; кург. $4-1,58$ м), значительно более мелкими впускные (кург. 2, погр. 2 - 0,63 м; кург. 2, погр. 3 - 0,7 м). Исключениями являются относительно глубокое впускное погребение в кург. 5 погр. 2 (1,03 м) и два очень мелких основных погребения (кург. 5, погр. $1-0,72$ м; кург. 3 - 0,4 м). Особенностью последнего является устройство захоронения на уровне материка, то есть могильная яма прорезала только слой погребенной почвы (рис. $4,1,2$ ), фиксация границ и формы ямы стала возможной исключительно благодаря «плотному каменному заполнению» [Зуев, Исмагилов, 1999, c. 108].
В трех курганах, наряду с рваным камнем, в насыпи и засыпке могил использовалась светлая речная галька. В кург. 1 она в большом количестве встречалась в нижней части заполнения могилы, имела крупные размеры (до 1-2 кг) и была обожжена. В насыпи кург. 4 «среди дикого камня довольно часто встречалась речная светлых тонов галька; ее было больше в центральной части насыпи и особенно в засыпке могилы» [Исмагилов, 1980, л. 8], что сближает ее с погр. 2 в кургане 1. Во впускном погр. 2 кург. 5 «засыпка состоит исключительно из белой речной гальки» [Исмагилов, 1980, л. 10]. В отличие от последнего случая, где можно говорить о преднамеренной забутовке могильной ямы речной галькой, ее попадание в засыпку погр. 2 кург. 1 и погр. 1 кург. 4 может быть связано с обрушением деревянного перекрытия. Так, для кург. 1 Р.Б. Исмагилов прямо отмечает, что «остатки костра вместе с обожженным камнем и речной галькой упали в яму после того, как рухнуло перекрытие» [Исмагилов, 1980]. Та же ситуация зафиксирована и для центрального погр. 1 кург. 2, где речная галька отсутствовала - его засыпка «глинистая в верхней части, включала довольно много угольков и камней и спускалась ко дну ямы не равномерно, а клином, что, очевидно, может объясняться тем, что они попали в яму после обвала сгоревшего, вероятно, перекрытия» [Зуев, Исмагилов, 1999, с. 107]. В единственном погребении кург. 4, засыпка которого насыщена светлой речной галькой, прослежено такое же «клиновидное» заполнение (рис. 5,1), что может свидетельствовать о наличии над этим погребением такого же провалившегося деревянного перекрытия, не сохранившегося или не зафиксированного при исследованиях ${ }^{4}$. Все эти данные позволяют вполне обоснованно говорить о наличии на перекрытиях погр. 2 кург. 1, погр. 1 кург. 2 и погр. 1 кург. 4 какихто каменных конструкций типа куч или «пирамидок», в состав которых в двух случаях (кург. 1 и 4) входила светлая речная галька, провалившихся внутрь могильной ямы вследствие сгорания (кург. 1 и 2) или истлевания (кург. 4) дерева.

Особенностью всех могильных ям являются наклонные стенки - достаточно плохо прослеживаемые в неглубоких впускных по- 
гребениях кург. 2 (рис. $3,11,14$ ) и очень четко фиксируемые в остальных случаях. Центральные погребения кург. 2 и кург. 4, являющиеся после погр. 2 кург. 1 самыми глубокими в могильнике (1,43 и 1,58 м соответственно), в придонной части дополнительно имели кольцевой подбой (полуподбой) шириной около 0,2 м и высотой 0,3 м (рис. 3,2, 5,2).

Три погребения $(37,5 \%)$ из исследованных восьми являются парными. Во всех случаях погребенные уложены на дно могил (в погр. 2 кург. 1 погребенные лежали на деревянных носилках (?), установленных на «растительном тлене», в кург. 4 - на органической подстилке, в неглубоком погр. 1 кург. 5 какая-либо органика не сохранилась), параллельно друг другу. В погр. 2 кург. 1 погребенные лежали головами на запад, в погребении кург. 4 - головами в противоположные стороны, на запад и восток, в погр. 1 кург. 5 - возможно, также (практически все кости полностью истлели, такое заключение делается на основе размещения погребального инвентаря [Исмагилов, 1980, л. 9; Зуев, Исмагилов, 1999, c. 109]) головами на запад-юго-запад и восток-северо-восток (рис. 6). В целом для всех погребений характерны западная (оба костяка в погр. 2 кург. 1, костяк 1 в кург. 4), западная с небольшим отклонением к югу (впускное погр. 3 кург. 2, центральное в кург. 3 и, вероятно, костяк 1 погр. 1 кург. 5), восточная (центральное погр. 1 кург. 2, костяк 2 центрального погребения в кург. 4) и восточная с небольшим отклонением к северу (костяк 2 погр. 1 кург. 5) ориентировки. Значительное отличие от этой «широтной» нормы имеют два впускных погребения (погр. 2 кург. 2 и погр. 2 кург. 5), в которых умершие (в погр. 2 кург. 2 кости не сохранились) уложены головами к югу с небольшим отклонением к западу.

Близость всех курганов Гумаровского некрополя, четко проявляющаяся в погребальной обрядности, также прослеживается по составу и типам сопроводительного инвентаря. В.Ю. Зуев и Р.Б. Исмагилов отнесли могильник к периоду, охватывающему конец VI рубеж V - IV вв. до н.э. [Зуев, Исмагилов, 1999, с. 110-111], считая, таким образом, что погребения в нем проводились на протяжении более 100 лет. Погребение 2 в кург. 1 (то есть основное «савроматское» в Большом Гума- ровском кургане) по форме золотых обкладок деревянного сосуда, очень отдаленно напоминающих происходящие из кург. 4 погр. 1 могильника Пятимары I, они отнесли к рубежу VI-V вв. до н.э. К этому же времени - на основании инвентаря, который близок «до полного совпадения некоторых его элементов» находкам в Саре, Черниговском и Бесобе, отнесено и погребение в кург. 3 (рис. 4). Курган 4 и основное погребение кург. 5 на основании типологии и процентного соотношения наконечников стрел отнесены к первой трети $\mathrm{V}$ в. до н.э. Центральное погребение кург. 2 также по наконечникам стрел отнесено к середине третьей четверти V в. до н.э. К еще более позднему времени - рубежу V-IV вв. до н.э. В.Ю. Зуев и Р.Б. Исмагилов отнесли впускные погребения этого кургана.

Несмотря на некоторую условность любых археологических построений, тем более хронологических, в данном случае авторами произведено равномерное и последовательное распределение комплексов в пределах всего $\mathrm{V}$ в. до н.э., немного более раннего и, возможно, немного более позднего времени. Основным датирующим признаком для В.Ю. Зуева и Р.Б. Исмагилова, не учитывая единичных аналогий, здесь стали бронзовые наконечники стрел (133 экз. из 5 комплектов) и в качестве принципиально важного хронологического маркера - наконечники с внутренней втулкой, сводчатой головкой и немного выступающими шипами (тип XII по К.Ф. Смирнову). Соавторы посчитали возможным отнести данный тип исключительно к VI-V вв. до н.э., однако уже К.Ф. Смирнов отмечал, что наиболее ранние наконечники типа XII появляются в VI в. до н.э., достигают своего расцвета в V в. до н.э. и существуют до II в. до н.э., становясь в колчанах IV-II вв. до н.э. достаточно редкими [Смирнов, 1961, с. 50]. С.Ю. Гуцалов также отмечает, что этот тип был достаточно многочисленным и имел распространение с раннескифского времени до III в. до н.э. [Гуцалов, 2004, с. 21]. Принципиально важными здесь являются выводы О.И. Куринских, проанализировавшей наконечники стрел, происходящие более чем из 50 раннекочевнических погребений, исследованных около с. Покровка на р. Илек. По ее данным, появление трехлопастных бронзовых наконечников стрел 
со сводчатой головкой и внутренней втулкой относится к V в. до н.э. (13,7 \%), максимум распространения приходится на конец $\mathrm{V}$-рубеж IV-III вв. до н.э. (65,3 \%), а в III в. до н.э., перед окончательным исчезновением, их количество резко снижается $(21,0 \%)$ [Куринских, 2011, с. 52-53, рис. 5]. Это не позволяет выделять в гумаровских материалах комплекты наконечников стрел, относящихся к концу VI или первой половине V в. до н.э., то есть даже для V в. до н.э. все они не являются ранними.

Подтверждение поздней (в пределах V в. до н.э.) датировки дает нам зеркало, найденное в кург. 3 (рис. 4,8). У него немного сплюснутый (овальный) диск размерами 15 × 16,6 см; расширяющаяся к основанию ручка длиной 12 см; широкий, треугольного сечения откованный валик, проходящий по краю диска и формирующий центральную, утонченную проковкой, округлую площадку. В ее центре - pезной циркульный орнамент в виде круга с вписанной в него шестилепестковой розеттой, края которой объединены вогнутыми дуговидными отрезками. На месте крепления рукояти к диску с обеих сторон зеркало орнаментировано бордюрами из зигзага и арок, выполненными точечными наколами (пунсоном). М.Ю. Трейстер расширение рукояти у основания и наличие на ней пунсонного орнамента на этих, изначально импортных, зеркалах, рассматривает как относительно поздние признаки, сформировавшиеся уже на территории Южного Урала [Трейстер, 2012, с. 126-128]. Одинарная шестилепестковая розетта встречается на зеркалах данного типа, начиная с самых ранних экземпляров (Кырык-Оба II, кург. 15), датированных еще концом VI - первой половиной $\mathrm{V}$ в. до н.э. [Гуцалов, 2010, с. 64, рис. 4,13 ], и вплоть до самых поздних (Переволочан I, кург. 11, погр. 2, 3; Авласово, кург. 3, погр. 2), относимых ко второй половине IV в. до н.э. [Сиротин, 2010, рис. 4,2, 5,2; Сиротин, 2013, с. 166, рис. 3,2]. Особенностью их является нанесение розетты пунсонной техникой. Ближайшей же (и единственной из известных) аналогией резной циркульной розетте из Гумарово является зеркало, происходящее из погр. 1 кург. 4 могильника Сара, датируемого рубежом V-IV вв. до н.э. [Федоров, Васильев, 2017, рис. 4]. Также эти экзем- пляры сближает расширенное основание рукояти - достаточно редкий признак, имеющий, как отмечалось выше, хронологическое значение. Все это позволяет рассматривать зеркало из кург. 3 могильника Гумарово как очень позднее и упрощенное подражание ближневосточным экземплярам (типа кург. 3 Покровки II и кург. 15 Кырык-Обы II), датировка которого может сближаться с саринским экземпляром. Вероятно, не случайно, что расстояние между могильниками Сара и Гумарово по прямой составляет всего 35 км.

Учитывая близость погребального обряда и сопровождающего инвентаря как повторяющегося в разных комплексах по категориям, так и очень близкого по типам (табл. 3), дату, полученную по наконечникам стрел и зеркалу, можно применить ко всему Гумаровскому могильнику и датировать его концом V началом IV в. до н.э. Ранее его дата в пределах конца $\mathrm{V}$ в. до н.э., на основании рассмотренного выше зеркала и типов мечей, синхронизируемых с амфорным материалом Елизаветинского могильника, была предложена В.Н. Васильевым [Васильев, 2004, с. 160].

Выше уже отмечалось, что все курганы Гумаровского могильника отличаются значительной близостью по погребальному обряду. К его характерным чертам относятся сами каменные насыпи, кольцевые валы из выкида, каменные пирамидки-выкладки из белой речной гальки на деревянном перекрытии, обожженность перекрытий, широкие овальные могильные ямы, наклонные стенки и кольцевые ниши-полуподбои, широтная (западная при наличии восточной) ориентировка погребенных, находки под насыпью и т. д. Ранее на основании этих признаков мной было предложено выделить особую «мугоджарскую» группу кочевников Южного Урала середины - второй половины I тыс. до н.э. Ее происхождение связывалось с достаточно массовой миграцией кочевников Казахстана в степи, лежащие к западу от Мугоджар [Савельев, 2018; Савельев, 2019, с. 42-43]. Дополнительно проведенный анализ погребального обряда по 129 комплексам савромато-раннесарматского времени, в которых наиболее полно представлены выделенные ранее признаки, позволил значительно детализировать данную картину [Савельев, 2021]. 
В целом вся выборка разделена на 3 группы (курганы земляные, курганы земляные с каменными конструкциями, курганы каменные) (табл. 4). При значительной внешней схожести они различаются представленностью тех или иных признаков (иногда - их полным отсутствием), территориальной приуроченностью и совстречаемостью в пределах одних могильников. При этом признаки, статистически характеризующие данные группы, в значительной степени можно считать полярными.

С группой 1 (42 комплекса) максимально связаны широкие овальные ямы, кольцевые полуподбои, широтная ориентировка могильных ям, широтная (западная и в меньшей степени восточная) ориентировка умерших головами. Комплексы группы 1 входят в состав крупных, в том числе и сильно различающихся по погребальному обряду курганных могильников (Новый Кумак, Уркач, Восточно-Курайлинский и др.), но известны и гомогенные некрополи (Аксай III, Булдурта I, Танаберген II). Территориально данные памятники занимают максимально восточные и южные части ареала расселения ранних кочевников Южного Урала, а единичные погребения присутствуют и в Западном Оренбуржье. Группа 1 близка наиболее широко распространенному типу 1 погребений социальной элиты кочевников Южного Урала VI-V вв. до н.э. [Мышкин, 2013, с. 219-220, рис. 2, прим. 4]. Отличия кроются в овальной форме могильных ям (100 \%), наличии кольцевых полуподбоев (33,3\%), ярусных $(16,7 \%)$ и диагональных $(11,9 \%)$ погребений. В целом можно говорить о том, что группа 1 отличается от стандартных «блюменфельдских» южноуральских традиций именно теми чертами, которые наиболее проявляются в группе 2 земляных курганах с различными каменными конструкциями.

Группа 2 отличается от предыдущей наличием каменных конструкций (каменное кольцо на древнем горизонте, заполнение могильной ямы, каменная выкладка над могильной ямой, панцирь, квадратная или прямоугольная каменная ограда) и представлена 58 комплексами. Для этой группы максимально характерно кольцо из выкида, следы горения в центре подкурганной площадки и внутри мо- гильной ямы, широкие овальные ямы, ярусные и диагональные погребения, ориентировка ямы по линии СВ-Ю3, юго-западные ориентировки головами умерших, а также ориентировки головой в северный сектор. Памятники группы 2 территориально находятся практически там же, но имеют большее распространение в степной и горно-степной части Южного Зауралья.

Присутствие самих каменных конструкций, двух-, трехкратное снижение удельного веса признаков, характерных для группы 1, такое же двух-, трехкратное увеличение удельного веса ряда признаков, незначительно представленных в группе 1, говорят о совершенно ином происхождении традиций, зафиксированных в курганах группы 2. Ближайшими аналогиями ей являются курганы кочевников Северного Казахстана, происходящие из степной зоны Казахского мелкосопочника от северных склонов Кокчетавской возвышенности до верховьев Ишима (могильники Бектениз, Улубай, Алыпкаш и т. д.) и относящиеся к северному локальному варианту тасмолинской культуры [Хабдулина, 1994, с. 79]. Отличие их от «мугоджарской» группы 2 - в основном в отсутствии широких овальных могильных ям и диагональных погребений, то есть тех признаков, которые присутствуют в группе 1 и могли сформироваться на основе взаимодействия с собственно «савроматским» (блюменфельдским) компонентом в степях между Орью и Илеком.

Группа 3, то есть собственно каменные курганы, представлена 29 комплексами, для которых, наряду с широкими овальными, характерны узкие овальные и неправильно-овальные (так называемые «трапециевидные»), а также прямоугольные ямы, наклонные стенки, ориентация могильных ям меридионально и по линии СЗ-ЮВ, ориентация головой на юг, юго-восток и восток. Курганы этой группы не образуют крупных могильников (за исключением Гумарово, о чем ниже) и в основном разбросаны одиночно с максимальным скоплением в горно-степной зоне Южного Зауралья [Савельев, 2000]. В ряде случаев они входят в состав более крупных гетерогенных могильников (Шаншар, Варна, Шеменевский, Шиликтысай). 
Курганы группы 3 близки группе 2 по значительному количеству признаков, однако часть из них представлена минимально (кольцевой валик из выкида, следы горения на подкурганной площадке, ярусные погребения, кольцевые полуподбои, широтная ориентировка могильных ям, ориентировка головой на запад и юго-запад). Вероятно, курганы группы 3 должны рассматриваться как своеобразный этнографический реликт раннесакского населения степной зоны Южного Зауралья [Таиров, 2007, рис. 1], сохранившийся в горно-степной зоне, полосе предгорий и единично в открытой степи как минимум до второй половины - конца IV в. до н.э. [Савельев, 2000, c. 36-37]. Таким образом, группа 3 близка по своему происхождению (но не идентична) с группой 2 и имеет очень малое количество признаков, максимально проявляющихся в группе 1.

По основным признакам погребального обряда Гумаровские курганы относятся к группе 2, отличие заключается только в полностью каменном составе насыпи. Bсе прочие признаки, в том числе и вхождение пяти однотипных курганов в один некрополь, практически не характерны для группы 3. Учитывая длительное сосуществование в восточной части Южного Урала нескольких различных по своему происхождению групп населения, являющихся носителями совершенно разных погребальных традиций, а также индивидуальных комбинаций проявлений данных традиций в каждом конкретном могильнике, можно уверенно говорить о том, что процессы взаимодействия были устойчивыми и проявлялись в первую очередь на уровне малых семейнородовых коллективов. Одним из таких некрополей и являлся Гумаровский курганный могильник, в очень ярком виде содержавший признаки, сформировавшиеся в зоне постоянного взаимодействия блюменфельдского и североказахстанского населения, но при этом, вероятно, имеющий черты, сближающие его с предшествующим раннесакским населением Южного Зауралья (каменная насыпь курганов и приуроченность к узкой полосе горностепной зоны).

Многочисленные аналогии Малым Гумаровским курганам, но проявляющиеся, как правило, отдельными или несколькими призна- ками, раскиданы по всей территории распространения памятников «мугоджарской» группы (рис. 1), но наиболее они распространены в верховьях р. Илек (могильники Акжар, Восточно-Курайлинский, Имангазы-Карасу и т. д.). Учитывая же наличие каменных насыпей, единственной близкой аналогией им являются I и II Аксеновские курганные могильники на p. Есауловский Аксай (1 100 км к западу-юго-западу от Гумарово и 100 км к югозападу от Волгограда). Широкие овальные могильные ямы, наклонные стенки, нишиполуподбои, широтная (западная при наличии восточной) и юго-западная ориентировка умерших, ярусные и диагональные погребения, захоронения «валетом», заполнение могильных ям камнем [Шилов, Очир-Горяева, 1997] - все это повсеместно представлено в мугоджарских памятниках Южного Урала. Наличие же широких прямоугольных и квадратных могильных ям, в том числе и с коллективными погребениями [Шилов, Очир-Горяева, 1997, рис. 4,8, 5,2, 14,1,4], также имеет значительное количество аналогий в восточной части Южного Урала, но уже в «блюменфельдских» памятниках [Смирнов, 1981]. Вероятно, появление этих компактных некрополей на правобережье Дона связано с участием кочевников Южного Урала в военно-политических событиях в Приазовье и Прикубанье V-IV вв. до н.э. и переселением части кочевников далеко на запад [Савельев, 2020].

\section{ПРИМЕЧАНИЯ}

\begin{abstract}
${ }^{1}$ При таком условном разделении могильника к его «Малой» части необходимо относить и сам «Большой» курган (№ 1), так как грандиозная каменная насыпь была сооружена именно над погребением явно не рядового ранга «савроматского» времени. Курганной насыпи, связанной именно с раннескифским погребением, в процессе исследований зафиксировано не было (об особенностях документирования и интерпретации этого кургана см.: [Ольховский, 2000, с. 269-271]). В то же время данный формат наименования позволяет четко разделять два разновременных комплекса Гумаровского курганного могильника.

${ }^{2}$ Октябрь 2003 года. Благодарю Е.Ф. Королькову (Государственный Эрмитаж) за предоставленную возможность ознакомления с коллекцией.
\end{abstract}


H.C. Савельев. Малые Гумаровские курганы скифо-сарматского времени на Южном Урале

${ }^{3}$ В момент исследования высота кургана не превышала 1 м [Зуев, Исмагилов, 1999, с. 105], однако, по данным автора раскопок, насыпь кургана в 1950-е гг. целенаправленно разбиралась для строительства завода в г. Кувандык. «С первого кургана было вывезено не менее 100-150 полуторок обломков дикого камня. <...> К моменту начала раскопок (июль 1980 г.) насыпь кургана представляла из себя неровное каменисто-щебенистое возвышение, местами выровненное до уровня окружающей почвы» [Исмагилов, 1981, л. 1-2].
${ }^{4}$ Вероятно, причиной полного истлевания дерева перекрытия над этим погребением является крайне малая высота самого кургана, сложенного из камня, - всего 0,26 м, то есть это дерево находилось при постоянном доступе воздуха и влаги, что значительно ускоряло процессы гниения. Курганы 1 и 2 , где сохранились следы деревянного перекрытия, имели значительно большую высоту - выше 2 м и 0,51 м, причем во втором случае перекрытие было полностью сожжено. 


\section{ИЛЛЮСТРАЦИИ}

\section{Таблииа 1. Гумаровские курганы. Размерные признаки}

Table 1. Gumarovo kurgans. Dimensional features

\begin{tabular}{|c|c|c|c|c|c|c|c|c|}
\hline Комплекс & $\begin{array}{c}\text { К-н: диа- } \\
\text { метр, м }\end{array}$ & $\begin{array}{c}\text { К-н: вы- } \\
\text { сота, м }\end{array}$ & $\begin{array}{c}\text { М/я: все- } \\
\text { го }\end{array}$ & $\begin{array}{c}\text { М/я: } \\
\text { форма }\end{array}$ & $\begin{array}{c}\text { М/я: дли- } \\
\text { на, м }\end{array}$ & $\begin{array}{c}\text { M/я: ши- } \\
\text { рина, м }\end{array}$ & $\begin{array}{c}\text { М/я: со- } \\
\text { отноше- } \\
\text { ние Д/Ш }\end{array}$ & $\begin{array}{c}\text { М/я: глу- } \\
\text { бина, м * }\end{array}$ \\
\hline $\begin{array}{c}\text { кург. 1 } \\
\text { (погр. 2) }\end{array}$ & 23 & 2 & 1 & овал & 6,0 & 5,2 & $1: 1,154$ & 2,2 \\
\hline кург. 2 & 11 & 0,51 & 3 & - & - & - & - & - \\
\hline $\begin{array}{c}\text { кург. 2, } \\
\text { погр. 1 }\end{array}$ & - & - & - & овал & 2,75 & 1,98 & $1: 1,4$ & 1,43 \\
\hline $\begin{array}{c}\text { кург. 2, } \\
\text { погр. 2 }\end{array}$ & - & - & - & пр/уг & 2,7 & 1,0 & $1: 2,7$ & 0,63 \\
\hline $\begin{array}{c}\text { кург. 2, } \\
\text { погр. 3 }\end{array}$ & - & - & - & овал & 2,7 & 0,9 & $1: 3$ & 0,7 \\
\hline $\begin{array}{c}\text { кург. 3 } \\
\text { (погр. 1) }\end{array}$ & 12 & 0,33 & 1 & овал & 3,8 & 2,5 & $1: 1,5$ & 0,4 \\
\hline $\begin{array}{c}\text { кург. 4 } \\
\text { (погр. 1) }\end{array}$ & 10 & 0,26 & 1 & овал & 3,23 & 2,2 & $1: 1,47$ & 1,58 \\
\hline кург. 5 & 10 & 0,26 & 2 & - & - & - & - & - \\
\hline $\begin{array}{c}\text { кург. 5, } \\
\text { погр. 1 }\end{array}$ & - & - & - & овал & 3,15 & 2,75 & $1: 1,145$ & 0,72 \\
\hline $\begin{array}{c}\text { кург. 5, } \\
\text { погр. 2 }\end{array}$ & - & - & - & овал & 2,97 & 1,66 & $1: 1,8$ & 1,03 \\
\hline
\end{tabular}

Примечание. *-глубина всех могильных ям приведена от уровня древней поверхности.

Note. ${ }^{*}$ - the depth of all burial pits is estimated from the historical surface level.

\section{Таблица 2. Гумаровские курганы. Сводные данные по погребальному обряду}

\section{Table 2. Gumarovo kurgans. Summary of the funeral rite}

\begin{tabular}{|l|c|c|c|c|c|c|c|}
\hline Комплекс & $\begin{array}{c}\text { Насыпь: } \\
\text { камень }\end{array}$ & $\begin{array}{c}\text { Кольцевой } \\
\text { вал }\end{array}$ & $\begin{array}{c}\text { Перекрытие } \\
\text { (сожжено) }\end{array}$ & $\begin{array}{c}\text { Находки } \\
\text { на ДГ }\end{array}$ & $\begin{array}{c}\text { Светлая (бе- } \\
\text { лая) галька }\end{array}$ & $\begin{array}{c}\text { М/я: овал прямо- } \\
\text { уг. }\end{array}$ \\
\hline $\begin{array}{l}\text { кург. 1 } \\
\text { погр. 2 })\end{array}$ & + & + & + & $+*$ & + & + & - \\
\hline $\begin{array}{l}\text { кург. 2, } \\
\text { погр. 1 }\end{array}$ & + & + & + & $+* *$ & - & + & - \\
\hline $\begin{array}{l}\text { кург. 2, } \\
\text { погр. 2 }\end{array}$ & - & - & - & - & - & - & + \\
\hline $\begin{array}{l}\text { кург. 2, } \\
\text { погр. 3 }\end{array}$ & - & - & - & - & - & + & - \\
\hline кург. 3 & + & - & - & $+* * *$ & - & + & - \\
\hline кург. 4 & + & - & - & $+* * * *$ & + & + & - \\
\hline $\begin{array}{l}\text { кург. 5, } \\
\text { погр. 1 }\end{array}$ & + & - & - & - & - & + & - \\
\hline $\begin{array}{l}\text { кург. 5, } \\
\text { погр. 2 }\end{array}$ & - & - & - & - & + & + & - \\
\hline Всего, \% & 100 & 40 & 40 & 80 & 37,5 & 87,5 & 12,5 \\
\hline
\end{tabular}

Примечания. * - зеркало и перевернутый жертвенник- у западного края могильной ямы; ** - в восточной поле - развал яйцевидного сосуда с примесью талька и отдельные фрагменты от сосуда с примесью шамота; *** - перевернутый жертвенник - у восточного края могильной ямы, фрагменты сосуда с примесью талька в центре подкурганной площадки; **** - разрозненные кости животных - в восточной половине кургана.

Notes. * - a mirror and a flipped-over credence - at the western end of the burial pit; ** - in the western area complete sherds of an egg-shaped vessel made with the addition of talc and shard fragments of the vessel with the addition of chamotte; *** - a flipped-over credence - at the eastern end of the burial pit, fragments of the vessel with the addition of talc - in the center of the under kurgan ground; **** - separate animal bones - in the eastern part of the kurgan. 
Н.С. Савельев. Малые Гумаровские курганы скифо-сарматского времени на Южном Урале

Окончание таблицы 2

End of Table 2

\begin{tabular}{|c|c|c|c|c|c|c|c|}
\hline Комплекс & $\begin{array}{c}\text { М/я: стенки } \\
\text { наклонные }\end{array}$ & $\begin{array}{c}\text { М/я: } \\
\text { кольц евой } \\
\text { подбой }\end{array}$ & Погр. парное & $\begin{array}{c}\text { Голова } \\
\text { на Запад } \\
\text { (с откл.) } \\
\end{array}$ & $\begin{array}{c}\text { Голова } \\
\text { на Восток } \\
\text { (с откл.) } \\
\end{array}$ & $\begin{array}{c}\text { Голова на } \\
\text { Ю3 }\end{array}$ & $\begin{array}{c}\text { Голова на } \\
\text { ЮЮЗ }\end{array}$ \\
\hline $\begin{array}{l}\text { кург. } 1 \\
\text { (погр. 2) }\end{array}$ & + & - & + & + & - & - & - \\
\hline $\begin{array}{l}\text { кург. 2, } \\
\text { погр. } 1\end{array}$ & + & + & - & - & + & - & - \\
\hline $\begin{array}{l}\text { кург. 2, } \\
\text { погр. } 2\end{array}$ & + & - & - & - & - & - & + \\
\hline $\begin{array}{l}\text { кург. 2, } \\
\text { погр. } 3\end{array}$ & + & - & - & - & - & + & - \\
\hline кург. 3 & + & - & - & + & - & - & - \\
\hline кург. 4 & + & + & + & + & + & - & - \\
\hline $\begin{array}{l}\text { кург. 5, } \\
\text { погр. } 1 \\
\end{array}$ & + & - & + & + & + & - & - \\
\hline $\begin{array}{l}\text { кург. 5, } \\
\text { погр. } 2\end{array}$ & + & - & - & - & - & - & + \\
\hline Всего, \% & 100 & 25 & 37,5 & 50 & 37,5 & 12,5 & 25 \\
\hline
\end{tabular}

Таблица 3. Гумаровские курганы. Сопровождающий инвентарь

Table 3. Gumarovo kurgans. Accompanying inventory

\begin{tabular}{|c|c|c|c|c|c|c|c|}
\hline Комплекс & $\begin{array}{c}\text { Железные } \\
\text { шильца }\end{array}$ & $\begin{array}{r}\text { Браслет } \\
\text { несомкн. }\end{array}$ & $\begin{array}{l}\text { Жертвен- } \\
\text { ник кам. }\end{array}$ & Зеркало & $\begin{array}{c}\text { Глиняный } \\
\text { сосуд }\end{array}$ & $\begin{array}{c}\text { Кости } \\
\text { животных }\end{array}$ & $\begin{array}{c}\text { Костяная } \\
\text { ложка }\end{array}$ \\
\hline кург. 1, погр. 2 & - & - & + & + & - & - & - \\
\hline кург. 2, погр. 1 & - & - & - & - & + & + & + \\
\hline $\begin{array}{l}\text { кург. 2, } \\
\text { погр. } 2\end{array}$ & - & - & - & - & + & - & - \\
\hline $\begin{array}{l}\text { кург. 2, } \\
\text { погр. } 3\end{array}$ & - & - & - & - & - & - & - \\
\hline кург. 3 & + & + & + & + & - & - & - \\
\hline кург. 4, кост. 1 & - & - & - & - & - & + & + \\
\hline кург. 4, кост. 2 & - & - & - & - & - & - & - \\
\hline $\begin{array}{l}\text { кург 5, погр. 1, } \\
\text { кост. } 1\end{array}$ & - & - & - & - & - & - & - \\
\hline $\begin{array}{l}\text { кугр. 5, погр. 1, } \\
\text { кост. } 2\end{array}$ & - & - & - & - & - & - & - \\
\hline $\begin{array}{l}\text { кург. } 5 \text {, } \\
\text { погр. } 2\end{array}$ & + & + & + & + & + & + & - \\
\hline
\end{tabular}

\section{Окончание таблицы 3}

End of Table 3

\begin{tabular}{|c|c|c|c|c|c|c|c|}
\hline Комплекс & $\begin{array}{c}\text { Сосуд } \\
\text { (дерево) }\end{array}$ & $\begin{array}{c}\text { Нож } \\
\text { длинный }\end{array}$ & Бусы & $\begin{array}{c}\text { Бронз. нак. } \\
\text { стрел }\end{array}$ & $\begin{array}{c}\text { Меч / } \\
\text { кинжал }\end{array}$ & $\begin{array}{c}\text { Поясной } \\
\text { крючок }\end{array}$ & $\begin{array}{c}\text { Глиняная } \\
\text { курильница }\end{array}$ \\
\hline кург. 1, погр. 2 & + & - & + & - & - & - & - \\
\hline кург. 2, погр. 1 & + & + & - & + & - & - & - \\
\hline кург. 2, погр. 2 & - & - & - & - & - & - & + \\
\hline кург. 2, погр. 3 & - & - & + & - & - & - & - \\
\hline кург. 3 & - & + & + & + & + & + & + \\
\hline кург. 4, кост. 1 & - & - & - & + & + & + & - \\
\hline кург. 4, кост. 2 & - & - & - & + & + & + & - \\
\hline $\begin{array}{l}\text { кург. 5, погр. 1, } \\
\text { кост. 1 }\end{array}$ & - & - & - & + & + & + & - \\
\hline $\begin{array}{l}\text { кург. 5, погр. 1, } \\
\text { кост. 2 }\end{array}$ & + & + & - & - & + & + & - \\
\hline кург. 5, погр. 2 & - & - & - & - & - & & - \\
\hline
\end{tabular}


N.S. Savelev. Small Gumarovo Kurgans of Scythian-Sarmatian Time at South Ural

Таблица 4. Мугоджарская группа ранних кочевников Южного Урала. Сводные данные

Table 4. The Mugodzharian group of early nomads of the Southern Urals. Summary data

\begin{tabular}{|c|c|c|c|c|}
\hline \multirow[b]{2}{*}{ Признак } & \multirow[b]{2}{*}{$\begin{array}{l}\text { ВСЕГО } \\
(129), \%\end{array}$} & \multicolumn{3}{|c|}{ Группы, \% } \\
\hline & & $\begin{array}{c}\text { Группа 1: } \\
\text { Земляные (42) }\end{array}$ & $\begin{array}{c}\text { Группа 2: } \\
\text { С кам. констр. (58) }\end{array}$ & $\begin{array}{c}\text { Группа 3: } \\
\text { Каменные (29) }\end{array}$ \\
\hline Основные погребения & 86,8 & 88,1 & 86,2 & 86,6 \\
\hline К-ны: земляные (все) & 72,9 & 44,7 & 90,0 & - \\
\hline К-ны: земля + камень & 4,6 & - & 10,0 & - \\
\hline К-ны: камень & 22,5 & - & - & $\mathrm{X}$ \\
\hline Камень в конструкции & 45,0 & - & $\mathrm{X}$ & - \\
\hline К-ны: земляные (без камня) & 32,6 & $\mathrm{X}$ & - & - \\
\hline Кольцо из выкида & 26,4 & 28,6 & 31,0 & 13,8 \\
\hline Горение в ЦК & 16,3 & 11,9 & 22,4 & 10,3 \\
\hline М/я овальная, в том числе: & 95,4 & 100 & 96,6 & 86,2 \\
\hline широкий & 72,4 & 76,2 & 73,2 & 64,0 \\
\hline узкий & 12,2 & 9,5 & 12,5 & 16,0 \\
\hline средний & 5,7 & 4,8 & 7,1 & 4,0 \\
\hline трапеция & 4,9 & 4,8 & 3,6 & 8,0 \\
\hline круглый & 4,9 & 4,8 & 3,6 & 8,0 \\
\hline М/я прямоугольная & 4,6 & 0 & 3,4 & 13,8 \\
\hline Горение в М/я & 4,7 & 9,5 & 31 & 20,7 \\
\hline Погребение ярусное & 15,5 & 16,7 & 19 & 6,7 \\
\hline Наклонные стенки & 31,8 & 31,0 & 29,3 & 44,8 \\
\hline Погребение диагональное & 10,9 & 11,9 & 15,5 & 0 \\
\hline Кольцевой полуподбой & 20,9 & 33,3 & 15,5 & 13,8 \\
\hline Заполнение М/я: камень & 28,7 & - & 32,8 & 62,1 \\
\hline Кам. выкладка над M/я & 30,2 & - & 58,6 & 17,2 \\
\hline Каменное кольцо & 12,5 & - & 44,8 & 20,7 \\
\hline Каменная ограда & 5,4 & - & 10,0 & - \\
\hline Панцирь & 3,9 & - & 8,6 & - \\
\hline Ориент. М/я: СВ-Ю3 & 21,7 & 11,9 & 32,8 & 13,8 \\
\hline $\begin{array}{l}\text { Ориент. М/я: 3В (+3С3- } \\
\text { ВЮВ) }\end{array}$ & 42,6 & 66,7 & 31,0 & 31,0 \\
\hline Ориент. М/я: круглые & 4,7 & 4,8 & 3,4 & 6,7 \\
\hline Ориент. М/я: ВСВ-ЗЮЗ & 6,2 & 4,8 & 6,9 & 6,7 \\
\hline Ориент. М/я: СЮ & 17,8 & 9,5 & 19,0 & 27,6 \\
\hline Ориент. М/я: С3-ЮВ & 7,0 & 2,4 & 6,9 & 13,8 \\
\hline $\begin{array}{l}\text { Ориент. головой: ШИ- } \\
\text { РОТН. }\end{array}$ & 49,9 & 68,8 & 36,9 & 38,4 \\
\hline Ориент. головой: 3 (+3Ю3) & 33,3 & 51,1 & 28,1 & 11,5 \\
\hline Ориент. головой: В (+ВСВ) & 9,8 & 13,3 & 3,5 & 15,4 \\
\hline $\begin{array}{l}\text { Ориент. головой: } \\
\text { шир / неопр. }\end{array}$ & 6,8 & 4,4 & 5,3 & 11,5 \\
\hline Ориент. головой: ЮЗ & 18,9 & 17,8 & 24,6 & 11,5 \\
\hline Ориент. головой: ЮВ & 6,1 & 8,9 & 1,8 & 11,5 \\
\hline $\begin{array}{l}\text { Ориент. головой: Ю } \\
\text { (+ЮЮВ) }\end{array}$ & 14,4 & 4,4 & 19,3 & 23,1 \\
\hline $\begin{array}{l}\text { Ориент. головой: } \\
\text { мер / неопр. }\end{array}$ & 2,3 & 0 & 3,5 & 3,8 \\
\hline $\begin{array}{l}\text { Ориент. головой: } \\
\text { С-сектор }\end{array}$ & 8,3 & 0 & 15,9 & 11,5 \\
\hline Ориент. головой: СВ & 3,8 & 0 & 5,3 & 7,7 \\
\hline Ориент. головой: С3 & 3,0 & 0 & 5,3 & 3,8 \\
\hline Ориент. головой: C & 1,5 & 0 & 3,5 & 0 \\
\hline
\end{tabular}


Окончание таблиць 4

End of Table 4

\begin{tabular}{|c|c|c|c|c|c|c|c|}
\hline \multirow[b]{2}{*}{ Признак } & \multicolumn{7}{|c|}{ По основным признакам, \% } \\
\hline & $\begin{array}{c}\text { Кольцо из } \\
\text { выкида } \\
\text { (34) }\end{array}$ & $\begin{array}{c}\text { Каменное } \\
\text { кольцо } \\
\text { (32) }\end{array}$ & $\begin{array}{c}\text { Костер в } \\
\text { мог. яме } \\
(28)\end{array}$ & $\begin{array}{c}\text { Голова на } \\
\text { юг (21) }\end{array}$ & $\begin{array}{c}\text { Кольцевой } \\
\text { полупод- } \\
\text { бой (27) }\end{array}$ & $\begin{array}{l}\text { Ярусные } \\
\text { погр. (20) }\end{array}$ & $\begin{array}{c}\text { Диаго- } \\
\text { нальные } \\
\text { погр. (14) }\end{array}$ \\
\hline Основные погребения & 97,0 & 93,7 & 100 & 76,2 & 92,6 & 100 & 85,7 \\
\hline К-ны: земляные (все) & 85,3 & 75,0 & 75,0 & 47,6 & 81,5 & 85,0 & 92,9 \\
\hline К-ны: земля + камень & 2,9 & 6,3 & 3,6 & 9,5 & 3,7 & 5,0 & 7,1 \\
\hline К-ны: камень & 11,8 & 18,8 & 21,4 & 38,1 & 14,8 & 10,0 & 0 \\
\hline Камень в конструкции & 52,9 & 81,3 & 64,3 & 42,9 & 33,3 & 55,0 & 64,3 \\
\hline К-ны: земляные (без камня) & 32,3 & - & 14,3 & 19,0 & 51,9 & 35,0 & 35,7 \\
\hline Кольцо из выкида & $\mathrm{X}$ & 43,8 & 50,0 & 9,5 & 25,9 & 20,0 & 21,4 \\
\hline Горение в ЦК & 38,2 & 28,1 & 50,0 & 4,8 & 25,9 & 30,0 & 28,6 \\
\hline М/я овальная, в том числе: & 97,0 & 93,8 & 96,4 & 95,2 & 100 & 100 & 100 \\
\hline широкий & 84,8 & 66,7 & 85,2 & 55,0 & 63,0 & 80,0 & 100 \\
\hline узкий & 3,0 & 16,7 & 7,4 & 35,0 & 18,5 & 15,0 & 0 \\
\hline средний & 6,1 & 6,7 & 0 & 5,0 & 14,8 & 5,0 & 0 \\
\hline трапеция & 3,0 & 3,3 & 3,7 & 0 & 0 & 0 & 0 \\
\hline круглый & 3,0 & 6,7 & 3,7 & 5,0 & 3,7 & 0 & 0 \\
\hline М/я прямоугольная & 2,9 & 6,3 & 3,6 & 4,8 & 0 & 0 & 0 \\
\hline Горение в M/я & 41,2 & 28,1 & $\mathrm{X}$ & 23,8 & 25,9 & 45,0 & 42,9 \\
\hline Погребение ярусное & 11,8 & 18,8 & 32,1 & 9,5 & 18,5 & $\mathrm{X}$ & 35,7 \\
\hline Наклонные стенки & 32,4 & 31,3 & 46,2 & 28,6 & 14,8 & 20,0 & 28,6 \\
\hline Погребение диагональное & 8,8 & 9,4 & 21,4 & 9,5 & 7,4 & 25,0 & $\mathrm{X}$ \\
\hline Кольцевой полуподбой & 20,6 & 21,9 & 25,0 & 19,0 & $\mathrm{X}$ & 25,0 & 14,3 \\
\hline Заполнение М/я: камень & 23,5 & 40,6 & 35,7 & 42,9 & 29,6 & 30,0 & 28,6 \\
\hline Кам. выкладка над M/я & 32,4 & 50,0 & 53,6 & 38,1 & 29,6 & 55,0 & 35,7 \\
\hline Каменное кольцо & 41,2 & $\mathrm{X}$ & 32,1 & 28,6 & 25,9 & 30,0 & 21,4 \\
\hline Каменная ограда & 0 & 3,1 & 10,7 & 4,8 & 3,7 & 15,0 & 7,1 \\
\hline Панцирь & 5,9 & 6,3 & 7,1 & 0 & 0 & 5,0 & 0 \\
\hline Ориент. М/я: СВ-Ю3 & 32,4 & 37,5 & 21,4 & - & 18,5 & 40,0 & 21,4 \\
\hline $\begin{array}{l}\text { Ориент. М/я: 3В (+3С3- } \\
\text { ВЮВ) }\end{array}$ & 50,0 & 21,9 & 50,0 & - & 48,1 & 45,0 & 42,9 \\
\hline Ориент. М/я: круглые & 2,9 & 6,3 & 3,6 & 4,8 & 3,7 & 0 & 0 \\
\hline Ориент. М/я: ВСВ-3Ю3 & 5,9 & 3,1 & 3,6 & - & 3,7 & 0 & 7,1 \\
\hline Ориент. М/я: СЮ & 5,9 & 18,8 & 14,3 & 95,2 & 14,8 & 10,0 & 14,3 \\
\hline Ориент. М/я: С3-ЮВ & 2,9 & 13,5 & 7,1 & - & 11,1 & 5,0 & 14,3 \\
\hline $\begin{array}{l}\text { Ориент. головой: ШИ- } \\
\text { РОТН. }\end{array}$ & 51,3 & 25,1 & 46,9 & - & 51,7 & 44,4 & 38,9 \\
\hline Ориент. головой: 3(+3Ю3) & 29,7 & 18,8 & 28,1 & - & 37,9 & 37,0 & 27,8 \\
\hline Ориент. головой: В (+ВСВ) & 10,8 & 0 & 9,4 & - & 13,8 & 7,4 & 11,1 \\
\hline $\begin{array}{l}\text { Ориент. головой: } \\
\text { шир / неопр. }\end{array}$ & 10,8 & 6,3 & 9,4 & - & 0 & 0 & 0 \\
\hline Ориент. головой: Ю3 & 29,7 & 25,0 & 21,9 & - & 17,2 & 33,3 & 27,8 \\
\hline Ориент. головой: ЮВ & 2,7 & 6,3 & 6,3 & - & 6,9 & 0 & 11,1 \\
\hline $\begin{array}{l}\text { Ориент. головой: Ю } \\
(+ \text { ЮЮВ }\end{array}$ & 2,7 & 18,8 & 15,6 & $\mathrm{X}$ & 17,2 & 11,1 & 5,6 \\
\hline $\begin{array}{l}\text { Ориент. головой: } \\
\text { мер / неопр. }\end{array}$ & 2,7 & 3,1 & 0 & - & 0 & 0 & 0 \\
\hline $\begin{array}{l}\text { Ориент. головой: } \\
\text { С-сектор }\end{array}$ & 10,8 & 22,0 & 9,4 & - & 6,8 & 11,1 & 16,7 \\
\hline Ориент. головой: СВ & 2,7 & 6,3 & 0 & - & 3,4 & 7,4 & 0 \\
\hline Ориент. головой: С3 & 2,7 & 9,4 & 6,3 & - & 3,4 & 3,7 & 11,1 \\
\hline Ориент. головой: C & 5,4 & 6,3 & 3,1 & - & 0 & 0 & 5,6 \\
\hline
\end{tabular}




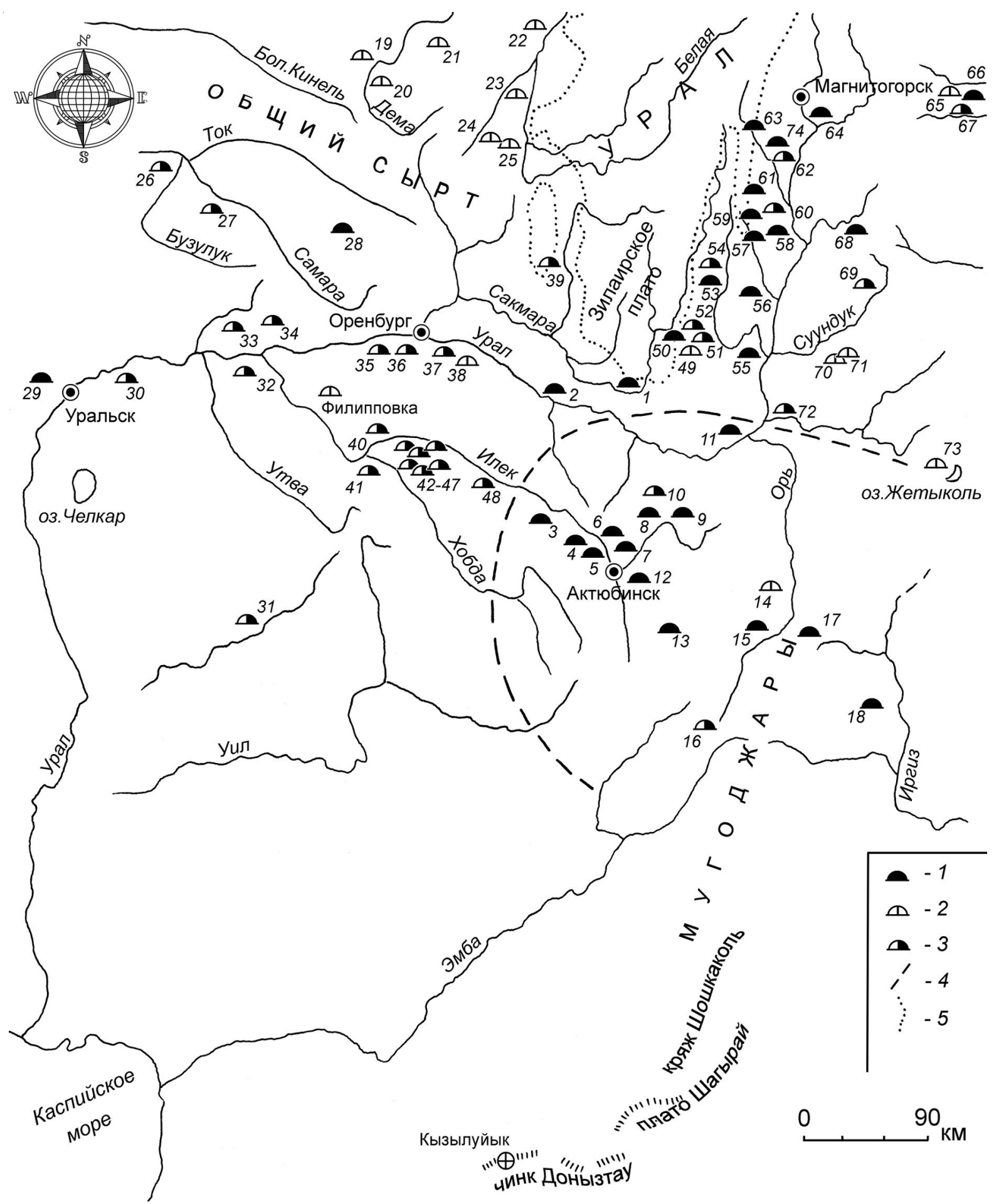

Рис. 1. Памятники ранних кочевников Южного Урала VII/VI - IV/III вв. до н.э.

Условные обозначения: 1 - мугоджарская группа (VII/VI - V вв. до н.э.);

2 - более поздние памятники (IV-III вв. до н.э.) с сохранением мугоджарских элементов;

3 - прочие памятники савроматского времени с присутствием мугоджарских элементов;

4 - границы компактного распространения памятников мугоджарской группы; 5 - современная граница лесной зоны.

Памятники: 1 - Гумарово; 2 - Гирьял; 3 - Целинный; 4 - Танаберген; 5 - Кызылжар; 6 - Восточно-Курайли; 7 - Акжар; 8 - Имангазы-Карасу; 9 - Шаншар; 10 - Шеменевский (Шпаки); 11 - Новотроицкий;

12 - Жаман-Каргала; 13 - Сарытау I; 14 - Матвеевский; 15 - Кудуксай; 16 - Уркач I; 17 - Жанабаз (Урбаз);

18 - Кепир (Жолуткен); 19 - Боголюбовка; 20 - Набережный; 21 - Уязыбашево; 22 - Леканды; 23 - Веселый;

24 - Юрматы; 25 - Загребаловка; 26 - Липовка; 27 - Медведка; 28 - Ивановская дюна; 29 - Белая Гора;

30 - Алебастрово II; 31 - Лебедевка; 32 - Жарсуат I; 33 - Болдырево; 34 - Барышников; 35 - Краснопартизанский; 


\section{Н.С. Савельев. Малые Гумаровские курганы скифо-сарматского времени на Южном Урале}

36 - Нижнепавловка; 37 - Бис-Оба; 38 - Башкирское стойло; 39 - Каскиново; 40 - Максутова землянка; 41 - Покровка; 42 - Мечетсай; 43 - Пятимары I; 44 - Близнецы; 45 - Увак; 46 - Черный Яр; 47 - Тара-Бутак; 48 - Акоба; 49 - Усть-Дергамыш; 50 - Янтышево; 51 - Переволочан I; 52 - Яковлевка; 53 - Юбилейный; 54 - Биш-Уба; 55 - Сагитово III; 56 - Валитово; 57 - Юмаш-Тау; 58 - Комсомол (Ургаза); 59 - Улек-Хазы-1; 60 - Сибай I; 61 - Гадельша; 62 - Альмухаметово; 63 - Давлетшино; 64 - Агаповские Горы; 65 - Елантау; 66 - Кесене; 67 - Варна; 68 - Александровский; 69 - Аландское; 70 - Урус-Кискен-2; 71 - Урус-Кискен-3; 72 - Новый Кумак; 73 - Озерный; 74 - Целинный (Альмухаметово)

Fig. 1. Monuments of the early nomads of the Southern Urals $7^{\text {th }} / 6^{\text {th }}-4^{\text {th }} / 3^{\text {rd }}$ centuries BC

Legend: 1 - Mugodzharian group $\left(7^{\text {th }} / 6^{\text {th }}-5^{\text {th }}\right.$ centuries BC);

2 - later sites $\left(4^{\text {th }}-3^{\text {rd }}\right.$ centuries BC) with the Mugodzharian elements preserved; 3 - other sites of the Sauromatian period with the presence of Mugodzharian elements;

4 - boundaries of compact distribution of the Mugodzharian group monuments; 5 - the modern border of the forest zone. Necropolis: 1 - Gumarovo; 2 - Giryal; 3 - Celinnyy; 4 - Tanabergen; 5 - Kyzylzhar; 6 - Vostochno-Kurayli;

7 - Akzhar; 8 - Imangazy-Karasu; 9 - Shanshar; 10 - Shemenevskiy (Shpaki); 11 - Novotroickiy;

12 - Zhaman-Kargala; 13 - Sarytau I; 14 - Matveevskiy; 15 - Kuduksay; 16 - Urkach I; 17 - Zhanabaz (Urbaz); 18 - Kepir (Zholutken); 19 - Bogolyubovka; 20 - Naberezhnyy; 21 - Uyazybashevo; 22 - Lekandy; 23 - Veselyy; 24 - Yurmaty; 25 - Zagrebalovka; 26 - Lipovka; 27 - Medvedka; 28 - Ivanovskaya dyna; 29 - Belaya Gora;

30 - Alebastrovo II; 31 - Lebedevka; 32 - Zharsuat I; 33 - Boldyrevo; 34 - Baryshnikov; 35 - Krasnopartizanskiy; 36 - Nizhnepavlovka; 37 - Bis-Oba; 38 - Bashkirskoe stoylo; 39 - Kaskinovo; 40 - Maksutova zemlyanka; 41 - Pokrovka; 42 - Mechetsay; 43 - Pyatimary I; 44 - Bliznecy; 45 - Uvak; 46 - Chernyy Yar; 47 - Tara-Butak; 48 - Akoba; 49 - Ust-Dergamysh; 50 - Yantyshevo; 51 - Perevolochan I; 52 - Yakovlevka; 53 - Yubileynyy;

54 - Bish-Uba; 55 - Sagitovo III; 56 - Valitovo; 57 - Yumash-Tau; 58 - Komsomol (Urgaza); 59 - Ulek-Hazy-1; 60 - Sibay I; 61 - Gadelsha; 62 - Almuhametovo; 63 - Davletshino; 64 - Agapovskie Gory; 65 - Elantau; 66 - Kesene; 67 - Varna; 68 - Aleksandrovskiy; 69 - Alandskoe; 70 - Urus-Kisken-2; 71 - Urus-Kisken-3; 72 - Novyy Kumak; 73 - Ozernyy; 74 - Celinnyy (Almuhametovo) 


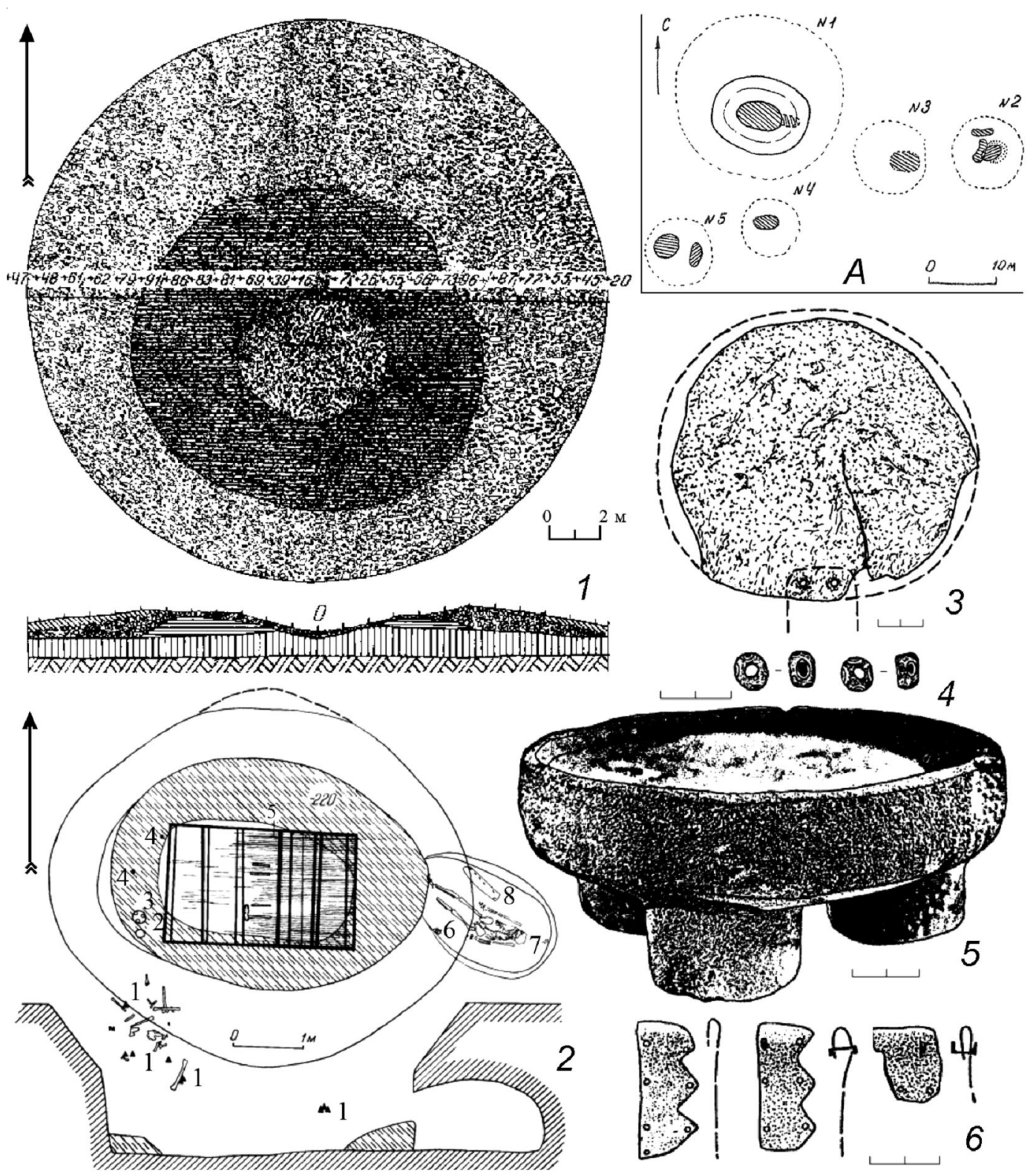

Рис. 2. План Гумаровского курганного могильника $(A)$ и находки из кургана 1:

1 - план кургана; 2 - план основной могильной ямы и бокового погр. № 3 раннескифского времени (1 - фрагменты сосуда из разрушенного погребения эпохи бронзы; 2 - зеркало; 3 - жертвенник; 4 - бусы; 5 - обкладки сосуда; 6-8 - находки из погр. № 3); 3 - бронзовое зеркало; 4 - пастовые бусы; 5 - каменный жертвенник; 6 - золотые обкладки деревянного сосуда

Fig. 2. Plan of the Gumarovskiy Cemetery $(A)$ and finds from the kurgan 1 :

1 - plan of the kurgan; 2 - plan of the main burial pit and side burial No. 3 of the Early Scythian time ( 1 - fragments of a vessel from a destroyed burial of the Bronze Age; 2 - mirror; 3 - altar; 4 - beads; 5 - vessel lining; 6-8 - finds from burial No. 3); 3 - bronze mirror; 4 - paste beads; 5 - stone altar; 6 - gold plates of a wooden vessel 


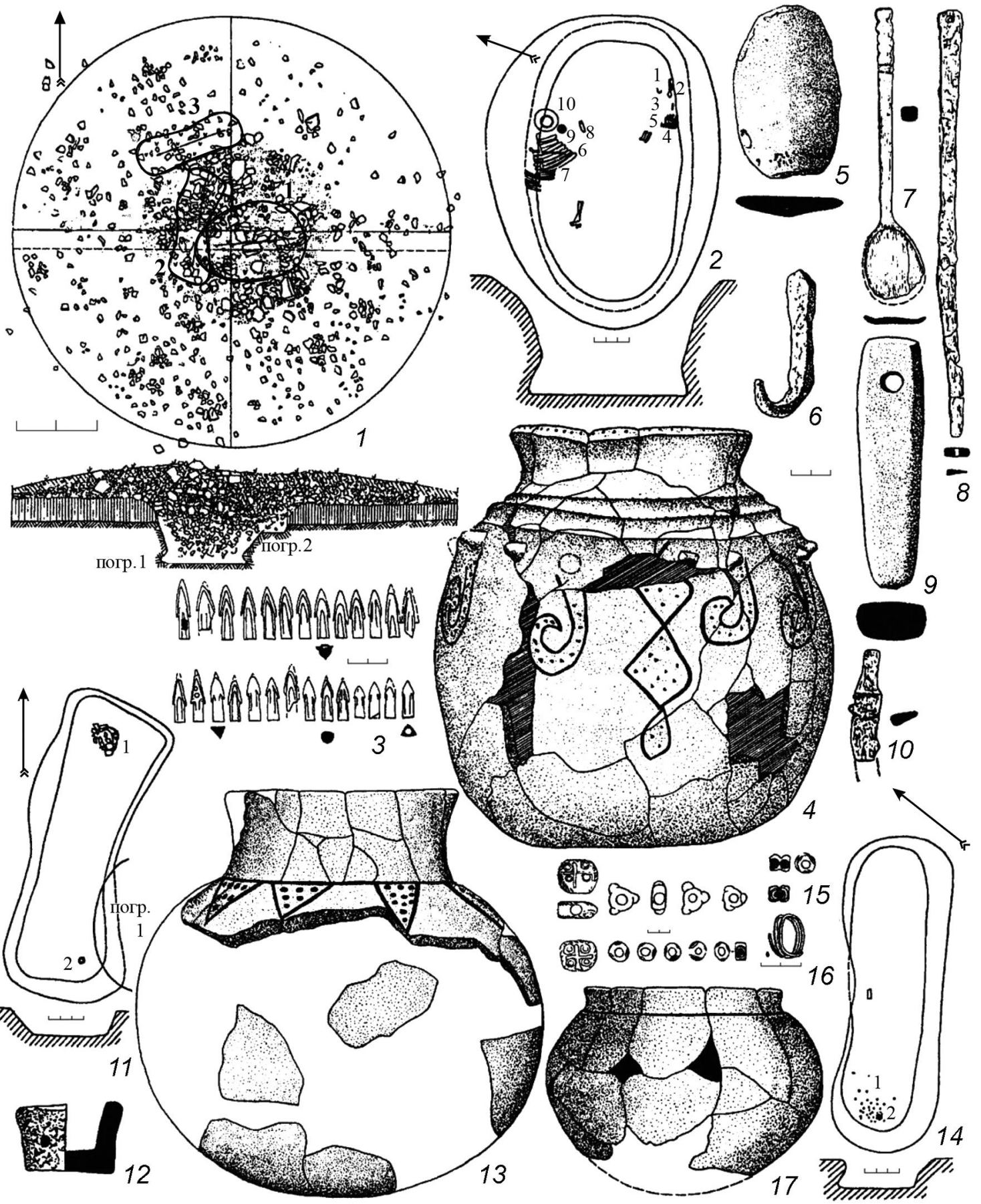

Рис. 3. Гумаровский курганный могильник. Курган 2:

1 - план кургана; 2 - погребение 1 (1 - ложечка; 2, 6 - ножи; 3 - колчанный крючок; 4 - наконечники стрел; 5 - каменная плитка; 7 - кости овцы; 8 - оселок; 9 - деревянный сосуд; 10 - глиняный сосуд);

3 - бронзовые наконечники стрел; 4 - сосуд; 5 - каменная плитка; 6 - колчанный крючок; 7 - костяная ложечка; 8,10 - железные ножи; 9 - оселок; 11 - погребение 2 (1 - сосуд; 2 - курильница); 12 - глиняная курильница; 13 - глиняный сосуд; 14 - погребение 3 (1 - стеклянные бусы; 2 - каменные брусочки); 15 - бусы; 16 - бронзовая серьга; 17 - глиняный сосуд, найденный под насыпью кургана

Fig. 3. Gumarovskiy Cemetery. Kurgan 2:

1 - plan of the kurgan; 2 - burial 1 ( 1 - spoon; 2, 6 - knives; 3 - quiver hook; 4 - arrowheads; 5 - stone tiles; 7 - sheep bones; 8 - touchstone; 9 - wooden vessel; 10 - vessel); 3 - bronze arrowheads; 4 - vessel; 5 - stone tiles;

6 - quiver hook; 7 - bone spoon; 8,10 - iron knives; 9 - touchstone; 11 - burial 2 (1 - vessel; 2 - censer); 12 - clay incense burner; 13 - vessel; 14 - burial 3 ( 1 - glass beads; 2 - stone blocks); 15 - beads; 16 - bronze earring; 17 - vessel found under the mound 

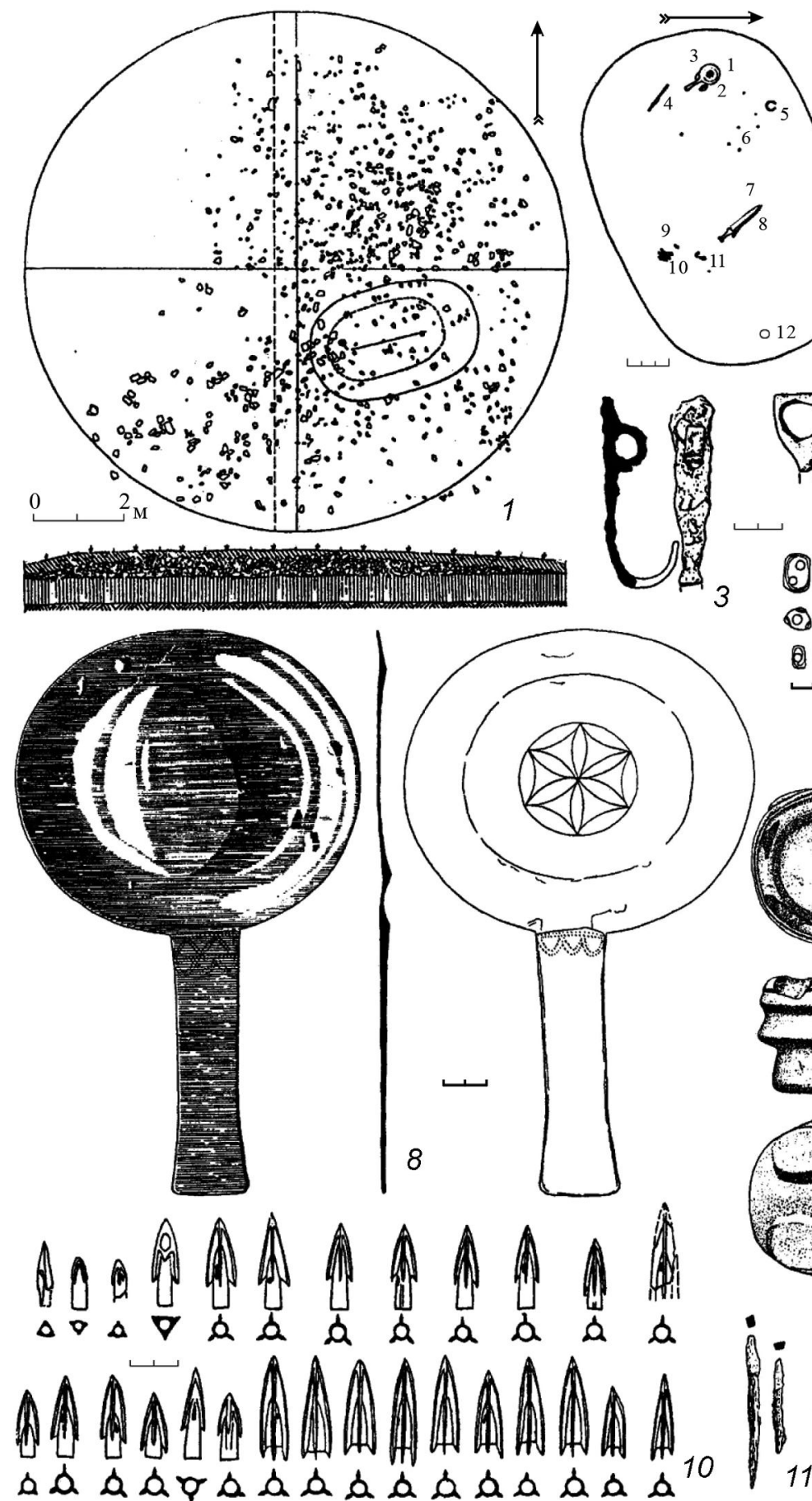

Рис. 4. Гумаровский курганный могильник. Курган 3 :

1 - план кургана; 2 - план погребения (1 - зеркало; 2 - раковина; 3 - реальгар; 4 - нож; 5 - браслет; 6 - бусы;

7 - меч; 8 - элемент ножен?; 9 - наконечники стрел; 10 - обломок удил; 11 - колчанный крючок;

12 - глиняный сосудик); 3 - железный колчанный крючок; 4 - обломок бронзовых удил; 5 - бусы; 6 - железный нож;

7 - железный меч; 8 - бронзовое зеркало; 9 - каменный жертвенник; 10 - бронзовые наконечники стрел; 11 - железные шильца; 12 - глиняный сосудик; 13 - серебряный браслет

Fig. 4. Gumarovskiy Cemetery. Kurgan 3:

1 - plan of the kurgan; 2 - burial plan ( 1 - mirror; 2 - shell; 3 - realgar; 4 - knife; 5 - bracelet; 6 - beads; 7 - sword;

8 - scabbard element?; 9 - arrowheads; 10 - bit chip; 11 - quiver hook; 12 - vessel); 3 - iron quiver hook;

4 - a piece of bronze bits; 5 - beads; 6 - iron knife; 7 - iron sword; 8 - bronze mirror; 9 - stone altar;

10 - bronze arrowheads; 11 - iron barbs; 12 - vessel; 13 - silver bracelet 
Н.С. Савельев. Малые Гумаровские курганы скифо-сарматского времени на Южном Урале

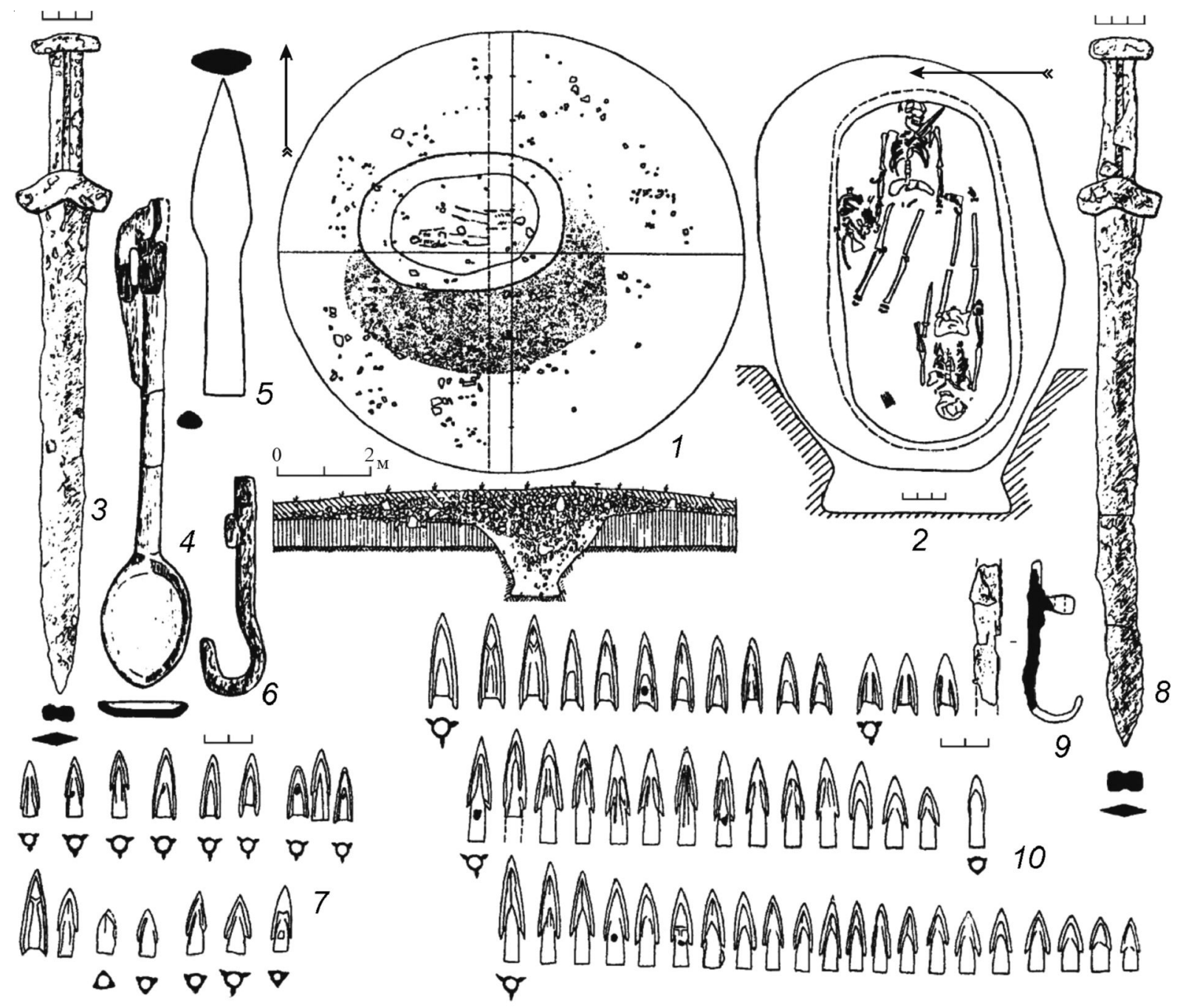

Рис. 5. Гумаровский курганный могильник. Курган 4:

1 - план кургана; 2 - план погребения.

Костяк 1: 3 - железный меч; 4 - костяная ложечка; 5 - железный наконечник копья; 6 - железный колчанный крючок; 7 - бронзовые наконечники стрел.

Костяк 2: 8 - железный меч; 9 - железный колчанный крючок; 10 - бронзовые наконечники стрел

Fig. 5. Gumarovskiy Cemetery. Kurgan 4:

1 - plan of the kurgan; 2 - burial plan.

Skeleton 1: 3 - iron sword; 4 - bone spoon; 5 - iron spearhead; 6 - iron quiver hooks; 7 - bronze arrowheads. Skeleton 2: 8 - iron sword; 9 - iron quiver hooks; 10 - bronze arrowheads 


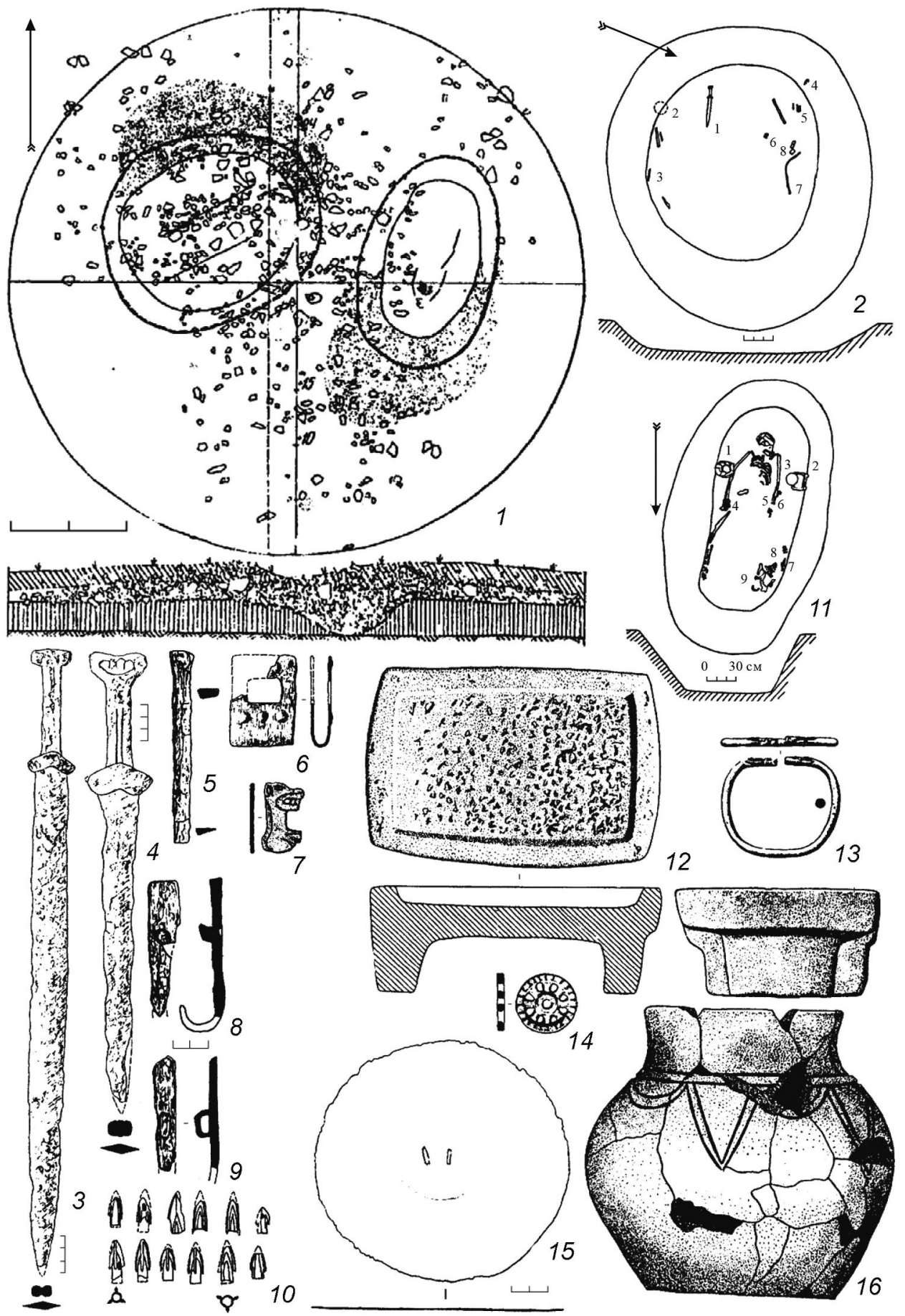

Рис. 6. Гумаровский курганный могильник. Курган 5:

1 - план кургана; 2 - погребение 1 (1, 7 - мечи; 2 - деревянный сосуд; 3 - нож; 4 - колчанный крючок; 5 - наконечники стрел; 6 - бляха; 8 - пряжка); 3, 6-8, 10 - костяк 1; 4-5, 9 - костяк 2; 11 - погребение 2 (1 - сосуд; 2 - жертвенник; 3 - зеркало; 4, 5 - браслеты; 6 - колесико; 7 - ножичек; 8 - кости овцы; 9 - железный предмет); 12 - каменный жертвенник; 13 - серебряный браслет; 14 - бронзовое колесико; 15 - бронзовое зеркало; 16 - глиняный сосуд

Fig. 6. Gumarovskiy Cemetery. Kurgan 5:

1 - plan of the kurgan; 2 - burial 1 ( 1,7 - swords; 2 - wooden vessel; 3 - knife; 4 - quiver hook; 5 - arrowheads; 6 - badge; 8 - buckle); 3, 6-8, 10 - skeleton 1; 4-5,9- skeleton 2; 11 - burial 2 (1 - vessel; 2 - altar; 3 - mirror; 4, 5 - bracelets; 6 - wheel; 7 - knife; 8 - sheep bones; 9 - iron object); 12 - stone altar; 13 - silver bracelet; 14 - bronze wheel; 15 - bronze mirror; 16 - vessel 


\section{СПИСОК ЛИТЕРАТУРЫ}

Берлизов Н. Е., 2011. Ритмы Сарматии. Савромато-сарматские племена Южной России в VII в. до н.э. - V в. н.э. Краснодар : Парабеллум. 320 с.

Васильев В. Н., 2004. К хронологии раннепрохоровского комплекса // Уфимский археологический вестник. Вып. 5. С. $153-172$.

Гуцалов С. Ю., 2004. Древние кочевники Южного Приуралья VII-I вв. до н.э. Уральск : ЗКОЦИА. 136 с.

Гуцалов С. Ю., 2010. Погребальные сооружения могильника Кырык-Оба ІІ в Западном Казахстане // Российская археология. № 2. С. 51-66.

Железчиков Б. Ф., 1994. База данных по погребальному обряду савроматской эпохи // Статистическая обработка погребальных памятников Азиатской Сарматии. Вып. 1 : Савроматская эпоха (VI-IV вв. до н.э.). М. : ИА РАН. С. 53-86.

Зуев В. Ю., Исмагилов Р. Б., 1999. Курганы у деревни Гумарово в Южном Приуралье // Археологические памятники Оренбуржья. Вып. 3. Оренбург : Печатный дом «Димур». С. 105-123.

Исмагилов Р. Б., 1980. Научный отчет об исследовании Гумаровской курганной группы в 1979 г. Стерлитамак // Архив ИИЯЛ УФИЦРАН.

Исмагилов Р. Б., 1981. Отчет об исследованиях на Южном Урале и раскопках Гумаровского кургана. Стерлитамак // Архив ИА РАН. Р-1. № 7624.

Исмагилов Р. Б., 1988. Погребение Большого Гумаровского кургана в Южном Приуралье и проблема происхождения скифской культуры // Археологический сборник Государственного Эрмитажа. Вып. 29. C. 29-47.

Исмагил Р., 2013. Гумаровский могильник в свете эпистолярного жанра // Уфимский археологический вестник. Вып. 13. С. 144-146.

Исмагил Р., Сунгатов Ф. А., 2011. Могильник Валит-2 и проблема датировки «шагреневой» культуры V-IV в. до н.э. Южного Урала // Археология Казахстана в эпоху независимости: итоги, перспективы : материалы Междунар. науч. конф., посвящ. 20-летию независимости Республики Казахстан и 20-летию Института археологии им. А.Х. Маргулана. Т. 2. Алматы : Институг археологии им. А.Х. Маргулана. C. $65-79$.

Исмагил Р., Сунгатов Ф. А., 2013. Памятники Яицкой культуры последней четверти V - IV вв. до н.э. на Южном Урале. Уфа : Белая река. $223 \mathrm{c}$.

Куринских О. И., 2011. Наконечники стрел ранних кочевников левобережного Илека VI-І вв. до н.э. (по материалам могильников у с. Покровка) // Российская археология. № 3. С. 42-54.

Мышкин В. Н., 2012. Конь и сбруя в курганах кочевников скифского времени на Южном Урале // Уфимский археологический вестник. Вып. 12. С. 81-96.

Мышкин В. Н., 2013. Типы погребального обряда социальной элиты кочевников Самаро-Уральского региона в VI-V вв. до н.э. // Известия Самарского научного центра Российской академии наук. Т. 15. № 1. C. 219-225.

Ольховский В. С., 2000. Монументальная скульптура кочевников Евразии: проблемы источниковедения // Археология, палеоэкология и палеодемография Евразии. М. : ГЕОС. С. 252-276.

Пшеничнюк А. Х., 1995. Переволочанский могильник // Курганы кочевников Южного Урала. Уфа : Гилем. C. $62-96$.

Савельев Н. С., 2000. Каменные курганы восточных предгорий Южного Урала и некоторые вопросы формирования прохоровской культуры // Уфимский археологический вестник. Вып. 2. С. 17-48.

Савельев Н. С., 2011. На границе Европы и Азии : факторы геокультурного развития Южного Урала // Антропология башкир. СПб. : Алетейя. С. 11-24.

Савельев Н. С., 2017. О южной границе лесных и лесостепных культур на Урале в I тысячелетии до н.э. // Поволжская археология. № 1. С. 114-129. DOI: https://doi.org/10.24852/pa2017.1.19.114.129.

Савельев Н. С., 2018. Малые Гумаровские курганы на Южном Урале : возможности культурной атрибуции и ее следствия для этнокультурной карты региона середины I тыс. до н.э. // Новое в исследованиях раннего железного века Евразии : проблемы, открытия, методики : тез. докл. Междунар. науч. конф. М. : МАКС Пресс. С. 135-137. 
Савельев Н. С., 2019. Южный Урал в I тыс. до н.э. - особая контактная зона на крайнем востоке Европы // Уфимский археологический вестник. Вып. 19. С. 39-50.

Савельев Н. С., 2020. Скифская узда в лесостепи Южного Приуралья: конечная точка западного импульca// Stratum plus. № 3. C. 31-52.

Савельев Н. С., 2021. Мугоджарская группа ранних кочевников Южного Урала скифо-сарматского времени // Исторические исследования. № 2. (В печати).

Сиротин С. В., 2010. Курган № 11 курганного могильника Переволочан в Зауральской Башкирии // Археология и палеоантропология Евразийских степей и сопредельных территорий. МИАР. № 13. М. : Таус. C. $323-338$.

Сиротин С. В., 2013. Катакомбные погребальные комплексы IV в. до н.э. могильника «Авласовские курганы» из Южного Зауралья // Исторические, философские, политические и юридические науки, культурология и искусствоведение. Вопросы теории и практики. № 11(37). Ч. ІІ. С. 163-169.

Смирнов К. Ф., 1961. Вооружение савроматов. МИА. № 101. М. : АН СССР. 163 с.

Смирнов К. Ф., 1981. Богатые захоронения и некоторые вопросы социальной жизни кочевников Южного Приуралья в скифское время // Материалы по хозяйству и общественному строю племен Южного Урала. Уфа : ИИЯЛ БФАН СССР. С. 68-90.

Таиров А. Д., 2007. Кочевники Урало-Казахстанских степей в VII-VI вв. до н.э. Челябинск : Изд-во ЮУрГУ. 274 с.

Таиров А. Д., 2015. Внутренняя Азия и культурные трансформации в степной Евразии I тысячелетия до н.э. // Древние культуры Северного Китая, Монголии и Байкальской Сибири : сб. тр. VI Междунар. науч. конф. Т. 3. Хух-Хото. С. 997-1001.

Таиров А. Д., 2016. Южное Зауралье в раннесакское и савроматское время // Константин Федорович Смирнов и современные проблемы сарматской археологии : материалы IX Междунар. науч. конф. «Проблемы сарматской археологии и истории». Оренбург : Изд-во ОГПУ. С. 275-279.

Трейстер М. Ю., 2012. Бронзовые зеркала из Южного Приуралья : ближневосточные и южно-азиатские импорты и местные подражания // Влияния ахеменидской культуры в Южном Приуралье (V-III вв. до н.э.). Т. 1. M. : Tayc. C. 120-133.

Федоров В. К., Васильев В. Н., 2017. Уздечный набор с бляхами в виде рыб из кургана № 4 могильника Сара в восточном Оренбуржье // Вестник ЮУрГУ. Серия «Социально-гуманитарные науки». Т. 17. № 1. C. $54-62$.

Хабдулина М. К., 1994. Степное Приишимье в эпоху раннего железа. Алматы : Ракурс. 170 с.

Чибилев А. А., Богданов С. В., 2011. Граница Европы и Азии: история вопроса, проблема верификации природных и культурно-исторических рубежей // Уральский исторический вестник. № 2 (31). С. 95-105.

Чибилев А. А., Чибилев Ант. А., 2012. Природное районирование Урала с учетом широтной зональности, высотной поясности и вертикальной дифференциации ландшафтов // Известия Самарского научного центра РАН. Т. 14, № 1(6). С. 1660-1665.

Чугунов К. В., 2000. К вопросу о формировании колчанного набора в восточных регионах скифского мира // Сохранение и изучение культурного наследия Алтая. Вып. ХІ. Барнаул : Изд-во АлтГУ. С. 165-168.

Шилов В. П., Очир-Горяева М. А., 1997. Курганы скифской эпохи из могильников Аксеновский-I-ІІ // Памятники предскифского и скифского времени на юге Восточной Европы. МИАР. № 1. М. : ИА РАН. С. $127-152$.

Яблонский Л. Т., 2007. Проблема хронологии и типологизации сарматских культур на современном этапе их изучения (в свете новейших материалов из Южного Приуралья) // Региональные особенности раннесарматской культуры : материалы семинара Центра изучения истории и культуры сарматов. Вып. II. Волгоград : Изд-во ВолГУ. С. 4-36.

Яблонский Л. Т., 2010. Прохоровка. У истоков Сарматской археологии // МИАР. № 12. М. : Таус. 384 с.

\section{REFERENCES}

Berlizov N.E., 2011. Ritmy Sarmatii. Savromato-sarmatskie plemena Yuzhnoy Rossii v VII v. do n.e. - V v. n.e. [Rhythms of Sarmatia. Sauromato-Sarmatian Tribes of Southern Russia in the VII Century BC-V Century AD]. Krasnodar, Parabellum Publ. 320 p. 
Vasilev V.N., 2004. K hronologii ranneprohorovskogo kompleksa [Towards Chronology of Early Prokhorovka Complex]. Ufimskiy arheologicheskiy vestnik [The Ufa Archaeological Herald], iss. 5, pp. 153-172.

Gutsalov S.Yu., 2004. Drevnie kochevniki Yuzhnogo Priuralya VII-I vv. do n.e. [Ancient Nomads of the Southern Urals from VII-I Centuries BC]. Uralsk, West-Kazakhstan Center of History and Archaeology. 136 p.

Gutsalov S.Yu., 2010. Pogrebalnye sooruzheniya mogilnika Kyryk-Oba II v Zapadnom Kazahstane [Burial Structures of Kyryk-Oba II Cemetery in Western Kazakhstan]. Rossiyskaya arkheologiya [Russian Archaeology], no. 2, pp. 51-66.

Zhelezchikov B.F., 1994. Baza dannyh po pogrebalnomu obryadu savromatskoy epohi [Database on the Funerary Rite of the Sauromatic Era]. Statisticheskaya obrabotka pogrebalnyh pamyatnikov Aziatskoy Sarmatii. Savromatskaya epoha (VI-IVvv. do n.e.) [Statistical Processing of Funerary Monuments of Asian Sarmatia. Sauromatic Era (VI-IV Centuries BC)], iss. 1, Moscow, IA RAS, pp. 53-86.

Zuev V.Yu., Ismagilov R.B., 1999. Kurgany u derevni Gumarovo v Yuzhnom Priuralie [Kurgans near the Village of Gumarovo in the Southern Urals]. Arheologicheskie pamyatniki Orenburzhya [Archaeological Sites of Orenburg Region], iss. 3, Orenburg, Pechatnyy dom «Dimur» Publ., pp. 105-123.

Ismagilov R.B., 1980. Nauchnyy otchet ob issledovanii Gumarovskoy kurgannoy gruppy v 1979 g. [Scientific Report on the Study of the Gumarovskaya kurgan Group in 1979]. Sterlitamak. Arkhiv IIYaL UFIC RAN.

Ismagilov R.B., 1981. Otchet ob issledovaniyah na Yuzhnom Urale i raskopkah Gumarovskogo kurgana [Report on Research in the Southern Urals and Excavations of the Gumarovskiy Kurgan]. Sterlitamak. Arhiv IA RAN. $\mathrm{R}-1$, no. 7624 .

Ismagilov R.B., 1988. Pogrebenie Bolshogo Gumarovskogo kurgana v Yuzhnom Priuralie i problema proiskhozhdeniya skifskoy kultury [The Burial of the Big Gumarovo Kurgan in the South Urals and the Problem of the Origin of the Scythian Culture]. Arheologicheskiy sbornik Gosudarstvennogo Ermitazha [Archaeological Collection of the State Hermitage Museum], iss. 29, pp. 29-47.

Ismagil R., 2013. Gumarovskiy mogilnik v svete epistolyarnogo zhanra [Gumarovskiy Cemetery in the Light of the Epistolary Genre]. Ufimskiy arheologicheskiy vestnik [The Ufa Archaeological Herald], iss. 13, pp. 144-146.

Ismagil R., Sungatov F.A., 2011. Mogilnik Valit-2 i problema datirovki «shagrenevoy» kultury V-IV v. do n.e. Yuzhnogo Urala [The Cemetery of Valit-2 and the Problem of Dating the "Shagreen" Culture of the VIV Century BC of the Southern Urals]. Arheologiya Kazahstana v epohu nezavisimosti: itogi, perspektivy. Materialy mezhdunar. nauch. konf., posvyashch. 20-letiy nezavisimosti Respubliki Kazahstan i 20-letiyu Instituta arheologii im. A.H. Margulana [Archeology of Kazakhstan in the Era of Independence: Results, Prospects. Materials of the International Scientific Conference, Dedicated to the $20^{\text {th }}$ Anniversary of Independence of the Republic of Kazakhstan and the $20^{\text {th }}$ anniversary of the A. H. Margulan Institute of Archaeology], vol. 2. Almaty, A. H. Margulan Institute of Archaeology, pp. 65-79.

Ismagil R., Sungatov F.A., 2013. Pamyatniki Yaitskoy kultury posledney chetverti V-IV vv. do n.e. na Yuzhnom Urale [Monuments of the Yaitskaya Culture of the Last Quarter of the V-IV Centuries BC in the Southern Urals]. Ufa, Belaya reka Publ. 223 p.

Kurinskih O.I., 2011. Nakonechniki strel rannih kochevnikov levoberezhnogo Ileka VI-I vv. do n.e. (po materialam mogilnikov u s. Pokrovka) [Arrowheads from the Early Nomads of the Ilek Left Bank, $6^{\text {th }}-1^{\text {st }} \mathrm{cc}$. BC (Based on the Materials from the Burial Grounds near Prokhorovka)]. Rossiyskaya arkheologiya [Russian Archaeology], no. 3, pp. $42-54$.

Myshkin V.N., 2012. Kon i sbruya v kurganah kochevnikov skifskogo vremeni na Yuzhnom Urale [Horse and Harness in the Kurgans of nomads of Scythian Time in the Southern Urals]. Ufimskiy arheologicheskiy vestnik [The Ufa Archaeological Herald], iss. 12, pp. 81-96.

Myshkin V.N., 2013. Tipy pogrebalnogo obryada sotsialnoy elity kochevnikov Samaro-Uralskogo regiona v VI-V vv. do n.e. [Types of Funeral Rites of the Social Elite of the Nomads of the Samara-Ural Region in the VI-V Centuries BC]. Izvestiya Samarskogo nauchnogo centra Rossiyskoy akademii nauk [News of the Samara Scientific Center of the Russian Academy of Sciences], vol. 15, no. 1, pp. 219-225.

Olhovskiy V.S., 2000. Monumentalnaya skulptura kochevnikov Evrazii: problemy istochnikovedeniya [Monumental Sculpture of the Nomads of Eurasia: Problems of Source Study]. Arheologiya, paleoekologiya $i$ paleodemograiya Evrazii [Archaeology, Paleoecology and Paleodemography of Eurasia]. Moscow, Geos Publ., pp. 252-276.

Pshenichnyuk A.H., 1995. Perevolochanskiy mogilnik [Perevolochansky Cemetery]. Kurgany kochevnikov Yuzhnogo Urala [Kurgans of Nomads of the Southern Urals]. Ufa, Gilem Publ., pp. 62-96. 
Savelev N.S., 2000. Kamennye kurgany vostochnyh predgoriy Yuzhnogo Urala i nekotorye voprosy formirovaniya prohorovskoy kultury [Mounds of Nomads of the Southern Urals]. Ufimskiy arheologicheskiy vestnik [The Ufa Archaeological Herald], iss. 2, pp. 17-48.

Savelev N.S., 2011. Na granitse Evropy i Azii: faktory geokulturnogo razvitiya Yuzhnogo Urala [On the Border of Europe and Asia: Factors of Geocultural Development of the Southern Urals]. Antropologiya bashkir [Anthropology of Bashkirs]. Saint Petersburg, Aleteyya Publ., pp. 11-24.

Savelev N.S., 2017. O yuzhnoy granitse lesnyh i lesostepnyh kultur na Urale v I tysyacheletii do n.e. [On the Southern Border of the Forest and Forest-Steppe Cultures in the Urals in the Ist Millennium BC]. Povolzhskaya arheologiya [The Volga Region Archaeology], no. 1, pp. 114-129. DOI: https://doi.org/10.24852/ pa2017.1.19.114.129.

Savelev N.S., 2018. Malye Gumarovskie kurgany na Yuzhnom Urale: vozmozhnosti kulturnoy atribucii i ee sledstviya dlya etnokulturnoy karty regiona serediny I tys. do n.e. [Maly Gumarovsky Kurgans in the Southern Urals: the Possibilities of Cultural Attribution and its Consequences for the Ethnocultural Map of the Region in the Middle of the First Millennium BC]. Novoe v issledovaniyah rannego zheleznogo veka Evrazii: problemy, otkrytiya, metodiki. Tezisy dokladov Mezhdunar. nauch. konf. [New Research in the Early Iron Age of Eurasia: Problems, Discoveries, Methods. Abstracts of Reports of the International Scientific Conference]. Moscow, MAKS Press Publ., pp. 135-137.

Savelev N.S., 2019. Yuzhnyy Ural v I tys. do n.e. - osobaya kontaktnaya zona na kraynem vostoke Evropy [The Southern Urals in the First Millennium BC as a Special Contact Zone in the far East of Europe]. Ufimskiy arheologicheskiy vestnik [The Ufa Archaeological Herald], iss. 19, pp. 39-50.

Savelev N.S., 2020. Skifskaya uzda v lesostepi Yuzhnogo Priuralya: konechnaya tochka zapadnogo impulsa [The Scythians Horse Harness in the Forest-steppe of Southern Cis-Urals: the End Point of the Western Impulse]. Stratum plus, no. 3, pp. 31-52.

Savelev N.S., 2021. Mugodzharskaya gruppa rannih kochevnikov Yuzhnogo Urala skifo-sarmatskogo vremeni [Mugodzhar group of early nomads of the Southern Urals of the Scythian-Sarmatian time]. Istoricheskie issledovaniya [Historical Research], no. 2. (in print).

Sirotin S.V., 2010. Kurgan № 11 kurgannogo mogilnika Perevolochan v Zauralskoy Bashkirii [Kurgan no. 11 of the Kurgan Cemetery was Perevolochan in Trans-Ural Bashkiria]. Arheologiya i paleoantropologiya Evraziyskih stepey $i$ sopredelnyh territoriy [Archaeology and Paleoanthropology of the Eurasian Steppes and Adjacent Territories]. Materialy i issledovaniya po arheologii Rossii, no. 13. Moscow, Taus Publ., pp. 323-338.

Sirotin S.V., 2013. Katakombnye pogrebalnye kompleksy IV v. do n.e. mogilnika «Avlasovskie kurgany» iz Yuzhnogo Zauralya [Catacomb Burial Complexes of the IV Century BC Cemetery "Avlasovskie Kurgans" from the Southern Trans-Urals]. Istoricheskie, filosofskie, politicheskie i yuridicheskie nauki, kulturologiya $i$ iskusstvovedenie. Voprosy teorii i praktiki [Historical, Philosophical, Political and Legal Sciences, Cultural Studies and Art History. Issues of Theory and Practice], no. 11 (37), p. II, pp. 163-169.

Smirnov K.F., 1961. Vooruzhenie savromatov [Sauromatian Armament]. Materialy i issledovaniya po arheologii SSSR, no. 101. Moscow, AS USSR. 163 p.

Smirnov K.F., 1981. Bogatye zahoroneniya i nekotorye voprosy sotsialnoy zhizni kochevnikov Yuzhnogo Priuralya v skifskoe vremya [Rich Burials and Some Issues of the Social Life of the Nomads of the Southern Urals in the Scythian Period]. Materialy po hozyaystvu i obshchestvennomu stroyu plemen Yuzhnogo Urala [Materials on the Economy and Social Structure of the Tribes of the Southern Urals]. Ufa, IIYaLBFAN SSSR, pp. 68-90.

Tairov A.D., 2007. Kochevniki Uralo-Kazahstanskih stepey v VII-VI vv. do n.e. [Nomads of Ural-Kazakhstan Steppes in the VII-VI Centuries BC]. Chelyabinsk, SUSU. 274 p.

Tairov A.D., 2015. Vnutrennyaya Aziya i kulturnye transformatsii v stepnoy Evrazii I tysyacheletiya do n.e. [Inner Asia and Cultural Transformations in Steppe Eurasia of the First Millennium BC]. Drevnie kultury Severnogo Kitaya, Mongolii i Baykalskoy Sibiri. Sb. tr. VI mezhdunar. nauch. konf. [Ancient Cultures of Northern China, Mongolia, and Baikal Siberia. Proceedings of the VI International Scientific Conference], vol. 3. HuhHoto, pp. 997-1001.

Tairov A.D., 2016. Yuzhnoe Zauralie v rannesakskoe i savromatskoe vremya [Southern Trans-Urals in the Early Saka and Sauromatian Times]. Konstantin Fedorovich Smirnov i sovremennye problemy sarmatskoy arheologii. Materialy IX Mezhdunar. nauch. konf. «Problemy sarmatskoy arheologii i istorii» [Konstantin Fedorovich Smirnov and Modern Problems of Sarmatian Archeology. Proceedings of the IX International Scientific Conference "Problems of Sarmatian Archeology and History"]. Orenburg, OSPU, pp. 275-279. 
Treister M.Yu., 2012. Bronzovye zerkala iz Yuzhnogo Priuralya: blizhnevostochnye i yuzhno-aziatskie importy i mestnye podrazhaniya [Bronze Mirrors from Southern Cis-Urals: Near Middle Eastern and South Asian Import Items and Local Imitations]. Vliyanie ahemenidskoy kultury v Yuzhnom Priuralie (V-III vv. do n.e.) [The Influence of the Achaemenid Culture in the Southern Urals (V-III Centuries BC)], vol. 1. Moscow, Taus Publ., pp. 120-133.

Fedorov V.K., Vasilev V.N., 2017. Uzdechnyy nabor s blyahami v vide ryb iz kurgana № 4 mogilnika Sara v vostochnom Orenburzhie [Bridle Set with Plaques in the Form of Fish from the Mound no. 4 of the Sara Burial Ground in the Eastern Orenburg Region]. Vestnik Yuzhno-Uralskogo gosudarstvennogo universiteta. Seriya "Socialnogumanitarnye nauki» [Bulletin of the South Ural State University. Series "Social and Humanitarian Sciences”], vol. 17, no. 1, pp. 54-62.

Habdulina M.K., 1994. Stepnoe Priishimie v epohu rannego zheleza [Steppe Priishimye in the Early Iron Age]. Almaty, Rakurs Publ. 170 p.

Chibilev A.A., Bogdanov S.V., 2011. Granitsa Evropy i Azii: istoriya voprosa, problema verifikatsii prirodnyh i kulturno-istoricheskih rubezhey [Border Between Europe and Asia: History of the Issue, the Problem of Verifying Natural and Cultural-Historical Boundaries]. Uralskiy istoricheskiy vestnik [Ural Historical Bulletin], no. 2(31), pp. 95-105.

Chibilev A.A., Chibilev Ant.A., 2012. Prirodnoe rayonirovanie Urala s uchetom shirotnoy zonal'nosti, vysotnoy poyasnosti i vertikal'noy differenciacii landshaftov [Natural Zoning of the Urals, Taking into Account Latitudinal Zoning, Altitudinal Zonation and Vertical Differentiation of Landscapes]. Izvestiya Samarskogo nauchnogo centra RAN [Proceedings of the Samara Scientific Center of the Russian Academy of Sciences], vol. 14, no. 1 (6), pp. 1660-1665.

Chugunov K.V., 2000. K voprosu o formirovanii kolchannogo nabora v vostochnyh regionah skifskogo mira [On the Formation of the Quiver Set in the Eastern Regions of the Scythian World]. Sohranenie i izuchenie kul 'turnogo naslediya Altaya [Preservation and Study of the Cultural Heritage of Altai], iss. XI. Barnaul, ASU, pp. 165-168.

Shilov V.P., Ochir-Goryaeva M.A., 1997. Kurgany skifskoy epohi iz mogil'nikov Aksenovskiy-I-II [Kurgans of the Scythian era from the Aksenovsky-I-II Burial Grounds]. Pamyatniki predskifskogo i skifskogo vremeni na yuge Vostochnoy Evropy [Pre-Scythian and Scythian Monuments in Southern Eastern Europe]. Materialy i issledovaniya po arheologii Rossii, no. 1. Moscow, IA RAN, pp. 127-152.

Yablonskiy L.T., 2007. Problema hronologii i tipologizatsii sarmatskih kultur na sovremennom ehtape ih izucheniya (v svete noveyshih materialov iz Yuzhnogo Priuralya) [The Problem of Chronology and Typology of Sarmatian Culture at the Present Stage of Their Study (In the Light of the Latest Materials from the South Urals)]. Regionalnye osobennosti rannesarmatskoy kul 'tury: materialy seminara Centra izucheniya istorii i kul 'tury sarmatov [Regional Features of the Early Sarmatian Culture: Materials of the Seminar of the Center for the Study of the History and Culture of the Sarmatians], iss. II. Volgograd, VolSU, pp. 4-36.

Yablonskiy L.T., 2010. Prohorovka. U istokov sarmatskoy arheologii [Prokhorovka. At the Root of Sarmatian Archaeology]. Materialy i issledovaniya po arheologii Rossii, no. 12. Moscow, Taus Publ. 384 p.

\section{Information About the Author}

Nikita S. Savelev, Candidate of Sciences (History), Associate Professor, Leading Research Scientist, Department of Archaeological Research of the Institute of History, Language and Literature, Ufa Federal Research Center of the Russian Academy of Sciences, Prosp. Oktyabrya, 71, 450054 Ufa, Russian Federation, sns_1971@mail.ru, https://orcid.org/0000-0002-3643-2388

\section{Информация об авторе}

Никита Сергеевич Савельев, кандидат исторических наук, доцент, ведущий научный сотрудник отдела археологических исследований Института истории, языка и литературы, Уфимский федеральный исследовательский центр Российской академии наук, просп. Октября, 71, 450054 г. Уфа, Российская Федерация, sns_1971@mail.ru, https://orcid.org/0000-0002-3643-2388 